This is a personal version of the accepted text of the final article, which is made available for scholarly purposes only, in accordance with the journal's author permissions. The full citation is: Suhartini, S., Heaven, S., Zhang, Y. and Banks, C.J., 2019. Antifoam, dilution and trace element addition as foaming control strategies in mesophilic anaerobic digestion of sugar beet pulp. International Biodeterioration \& Biodegradation, 145, p.104812. https://doi.org/10.1016/j.ibiod.2019.104812

\title{
Antifoam, dilution and trace element addition as foaming control strategies in mesophilic anaerobic digestion of sugar beet pulp
}

Sri Suhartini ${ }^{1,2}$, Sonia Heaven ${ }^{1}$, Yue Zhang ${ }^{1}$, and Charles J. Banks ${ }^{1}$

${ }^{1}$ Faculty of Engineering and the Environment, University of Southampton, Southampton, SO17 1BJ, UK

${ }^{2}$ Present address: Department of Agroindustrial Technology, Faculty of Agricultural Technology, Universitas Brawijaya, Jl. Malang, 65145, Indonesia

(E-mail: ssuhartini@ub.ac.id,sh7@soton.ac.uk,Y.Zhang@soton.ac.uk, C.J.Banks@soton.ac.uk)

Corresponding author:

S. Suhartini, Department of Agro-industrial Technology, Faculty of Agricultural Technology, Universitas Brawijaya, Jl. Malang, 65145, Indonesia

E-mail: ssuhartini@ub.ac.id

\begin{abstract}
The effectiveness of foaming control strategies, including trace element addition, feedstock dilution and use of antifoams, was assessed for the anaerobic digestion of sugar beet pulp (SBP) at laboratory scale under mesophilic conditions. Semi-continuous digestion at an organic loading rate (OLR) of $2 \mathrm{~g} \mathrm{VS} \mathrm{L}^{-1}$ day $^{-1}$ resulted in methane yields of $0.316 \mathrm{~L} \mathrm{CH}_{4} \mathrm{~g}^{-1}$ of volatile solids (VS), with a VS destruction rate of $\sim 91 \%$. At OLR of $3 \mathrm{~g} \mathrm{VS} \mathrm{L}^{-1}$ day $^{-1}$ or above, foaming occurred, accompanied by small increases in alkalinity ratio and volatile fatty acid (VFA) concentrations and a slight fall in specific biogas and methane production, indicating a minor reduction in process stability and performance. At OLR $5 \mathrm{~g} \mathrm{VS} \mathrm{L}^{-1} \mathrm{day}^{-1}$ foaming was persistent and severe. In contrast, digesters fed at OLR $5 \mathrm{~g} \mathrm{VS} \mathrm{L}^{-1}$ day $^{-1}$ and supplemented with selected trace elements showed stable performance with no foaming. Dilution has proved an effective control strategy for other feedstocks, but feeding with diluted SBP $(1: 1 \mathrm{w} / \mathrm{w})$ led to a decline in gas production and operational stability, with no significant benefits in eliminating foaming. Seven antifoams were tested for foam reduction and effects on batch digestion at a range of concentrations. Addition of certain antifoams at dosages of $0.5 \mathrm{~mL} \mathrm{~L}^{-1}$ or more could inhibit gas production. A selected antifoam agent was then trialled in semi-continuous digestion at OLR 5 g VS L-1 day ${ }^{-1}$. Repeated high antifoam dosing of $1 \mathrm{~mL} \mathrm{~L}^{-1}$ digestate was required to reduce foaming, and eventually proved inhibitory. More reliable screening tests are needed for antifoam selection, as batch toxicity testing may not provide a satisfactory guide to performance in continuous operation.
\end{abstract}

Keywords: Sugar beet pulp; foaming; organic loading rate; trace elements; antifoam; anaerobic digestion 


\section{Introduction}

Sugar Beet Pulp (SBP), a solid organic residue, arises from processing of sugar beet worldwide, particularly in Europe and the USA. In the UK, the production of sugar beet in 2017 was 8.9 million tonnes from 111,000 hectares (Defra, 2017). British Sugar, the leading sugar supplier in the UK, processes 8 million tonnes annually and generates 500,000 tonnes of SBP which is mainly used as cattle feed (British Sugar, 2019). Anaerobic digestion (AD) could provide a cost-effective alternative means of obtaining renewable energy from these large tonnage quantities. Other potential economic benefits include reduced material handling and transport costs, and in some cases better revenue returns from energy production compared to the animal feed market (Parawira et al., 2008).

Experimental studies have looked at the AD of SBP under a range of operating conditions, including at different organic loading rates (OLR) and temperatures (Brooks et al., 2008; Suhartini et al., 2014; Moeller and Zehndrorf, 2017). Suhartini et al. (2014) found that in mesophilic AD of SBP at high loadings the process was susceptible to foaming, with poor dewaterability of the digestate. Brooks et al. (2008), Stoyanova et al. (2014), Moeller et al. (2015a) and Lindorfer and Demmig (2016) also reported similar problems. Foaming is a significant issue for AD plants as it is associated with reduced process efficiency and biogas productivity (He et al., 2017; Moestedt et al., 2017; Jiang et al., 2018; Moeller et al., 2018), as well as a risk of pipe blockages and consequent increases in operating costs (Pognani et al., 2017).

Foaming appears to have a complex set of causes including biological, feedstock-related and operational factors. Biological factors include the presence of excessive numbers of filamentous bacteria (such as Gordonia and Microthrix) (Ganidi et al., 2011; Lienen et al., 2014; Subramanian and Pagilla, 2014; Subramanian et al., 2015; He et al., 2017); or of foaming bacteria (Nocardia and Desulfotomaculum) (Kougias et al., 2014a). Feedstock issues include substrate type or composition (Kougias et al., 2013a, 2014b; Lienen et al., 2014; Subramanian and Pagilla, 2014; Moeller and Görsch, 2015; Moeller et al., 2015b, 2016; Lindorfer and Demmig, 2016); particle size and fibre content (Moeller et al., 2016; Van Weelden et al., 2016); and the presence of surface active agents such as oils and grease (Subramanian and Pagilla, 2014) or fulvic acid (Pognani et al., 2017). Process or operational factors may include high organic loading rate (overloading) or inconsistent feed to the digester (Ganidi et al., 2011; Kougias et al., 2013a, 2013b , 2014b, 2014c, 2015b; Moeller and Görsch, 2015; Moeller et al., 2012a, 2015a, 2015b; Suhartini et al., 2014); digester configuration (Ganidi et al., 2009) or mixing intensity and pattern (Subramanian and Pagilla, 2014; Kougias et al., 2014b; Subramanian et al., 2015); temperature changes (Siebels and Long, 2013; Kougias et al., 2014b; Moeller and Görsch, 2015; Lindorfer and Demmig, 2016; Moestedt et al., 2017); and abrupt degassing or viscosity changes (Moeller et al., 2012b, 2015b; Lindorfer and Demmig, 2016).

Several measures for foaming control have been reported, including mechanical, thermal and enzymatic treatments (Jiang et al., 2018; Moeller et al., 2018); steam explosion and ultrasound pre-treatments (Alfaro et al., 2014); reduced digester mixing and the use of surface sludge sprays (Subramanian and Pagilla, 2014). In full-scale AD plants, various strategies have been applied to control foam formation, such as decreasing the interval between the feed/mix cycles (Bartek et al., 2015; Xu et al., 2018); addition of micronutrients and reduction of OLR (Moeller and Görsch, 2015); avoidance of foam-forming substrates, and optimisation of mixing (Lindorfer and Demmig, 2016). Several studies have also reported that dilution of SBP with water minimised foaming without affecting biogas production (Demirel and Scherer, 2009; Fang et al., 2011; Moeller et al., 2012b). A study by Moeller and Zehnsdorf (2017) reported that the addition of some commonly available synthetic fertilisers (e.g. urea, 
ammonium nitrate) to the digester at certain concentrations had a foam-reducing effect without inhibiting biogas production in digestion of SBP.

Trace elements (TE) are known to be important to anaerobic microorganisms and an adequate supply is essential to maintain specific gas production and process stability (Demirel and Scherer, 2011). Škrbić et al. (2010) reported that TE concentrations in sugar beet are low. Some studies have also indicated that lack of TE may be associated with foaming (Moeller and Görsch, 2015), and that TE addition can minimise foaming occurrence in anaerobic digesters (Karlsson et al., 2012; Lindorfer and Demmig, 2016). Other researchers have noted that co-digesting SBP with other feedstocks such as pig manure (Aboudi et al., 2015), cow manure (Aboudi et al., 2016) and sewage sludge and poultry manure (Borowski and Kucner, 2019) could offer a means of providing essential micro- and macro-nutrients and thus help to avoid foaming.

The use of antifoams to control or reduce the occurrence of foaming in digesters has been reported in several studies (Kougias et al., 2013b; 2014c; 2015a; 2015b; Moeller and Görsch, 2015; Lindorfer and Demmig, 2016; Moeller et al., 2016, 2018; Jiang et al., 2018; Xu et al., 2018). Cooney et al. (2007) studied two-phase AD of a mixture of glucose, yeast extract, peptone and macro-nutrients at various loading rates. The addition of $0.02 \mathrm{~mL} \mathrm{~L}^{-1}$ of silicone antifoam (antifoam A, Sigma, UK) was able to reduce the occurrence of foaming without any reported disturbances in digestion performance. Kougias et al. (2014c) found that addition of oils (e.g. rapeseed oil, octanoic acid and oleic acid) was able to reduce foaming. Kougias et al. (2015b) reported that the performance of rapeseed oil antifoams was superior to that of oleic acid in suppressing foaming caused by proteins or lipids. Their study further confirmed that addition of natural oil-based antifoams was able to stimulate biogas production, indicating no inhibition of the digestion process. Similarly, Lindorfer and Demmig (2016) noted that addition of vegetable oil-based and synthetic antifoams can suppress foaming for long periods if used carefully. Despite this, effective screening tests are still needed to confirm the causes of foaming and the long-term effects of different antifoams on AD performance (Lindorfer and Demmig, 2016).

Despite the recent upsurge of interest in foaming and in awareness of its operational significance, there is still a lack of information on the choice of control strategies to achieve stable performance in sugar beet pulp-based digesters. The current work therefore looked at a number of potential control strategies including TE addition, dilution, and use of antifoams. The addition of a selected antifoam was also investigated in both batch and semi-continuous mode to evaluate any effects in long-term operation.

\section{Materials and methods}

\subsection{Feedstock and inoculum}

Sugar beet pulp was collected fresh from British Sugar's Wissington Sugar Factory, Kings Lynn, UK, then packed into 4-L containers and frozen at approximately $-20{ }^{\circ} \mathrm{C}$. Before using, it was thawed for at least 24 hours at room temperature, then stored at $4{ }^{\circ} \mathrm{C}$. Feedstock properties were as reported in Suhartini et al. (2014).

Unless otherwise noted, inoculum for semi-continuous digestion trials was prepared by mixing at a 1:1 volume ratio digestates from mesophilic anaerobic digesters treating sugar beet pulp at a pilot scale (British Sugar, Wissington, UK) and municipal wastewater biosolids (Millbrook Wastewater Treatment Plant (WWTP), Southampton, UK).

\subsection{Trace elements solutions}

Two TE solutions were prepared, composed respectively of cations and oxyanions as follows: cations $10 \mathrm{mg} \mathrm{L}^{-1} \mathrm{Fe}\left(\right.$ as $\left.\mathrm{FeCl}_{2} \cdot 4 \mathrm{H}_{2} \mathrm{O}\right) ; 1 \mathrm{mg} \mathrm{L}^{-1} \mathrm{Co}\left(\mathrm{CoCl}_{2} \cdot 6 \mathrm{H}_{2} \mathrm{O}\right), \mathrm{Mn}$ 
$\left(\mathrm{MnCl}_{2} \cdot 4 \mathrm{H}_{2} \mathrm{O}\right)$, $\mathrm{Ni}\left(\mathrm{NiCl}_{2} \cdot 6 \mathrm{H}_{2} \mathrm{O}\right), \mathrm{Zn}\left(\mathrm{ZnCl}_{2}\right) ; 0.1 \mathrm{mg} \mathrm{L}^{-1} \mathrm{Cu}\left(\mathrm{CuCl}_{2} \cdot \mathrm{H}_{2} \mathrm{O}\right), \mathrm{B}\left(\mathrm{H}_{3} \mathrm{BO}_{3}\right)$ and $\mathrm{Al}$ $\left(\mathrm{AlCl}_{3} \cdot 6 \mathrm{H}_{2} \mathrm{O}\right)$; oxyanions $0.1 \mathrm{mg} \mathrm{L}^{-1} \mathrm{Mo}\left(\mathrm{NH}_{4}\right)_{6} \mathrm{Mo}_{7} \mathrm{O}_{24} \cdot 4 \mathrm{H}_{2} \mathrm{O}$, Se $\left(\mathrm{Na}_{2} \mathrm{SeO}_{3}\right)$ and $\mathrm{W}$ $\left(\mathrm{Na}_{2} \mathrm{WO}_{4} \cdot 2 \mathrm{H}_{2} \mathrm{O}\right)$ based on a modified recipe from Banks et al. (2012). These were added to TE-supplemented digesters at a rate of $1 \mathrm{~mL}$ of each solution for every $1 \mathrm{~L}$ of digestate removed.

\subsection{Biochemical methane potential (BMP) test}

This assay was carried out at $37 \pm 1{ }^{\circ} \mathrm{C}$ in 0.5 - $\mathrm{L}$ digesters which were mixed manually once per day. Inoculum was taken from the digester at Millbrook WWTP. The inoculum-tosubstrate ratio was $\sim 4: 1$ based on the VS content of the materials. Tests were carried out in triplicate against controls with no substrate added and positive controls of cellulose (C6288, Sigma-Aldrich Ltd, UK). Biogas was collected in 1-L collection cylinders using a 75\% saturated sodium chloride barrier solution adjusted to $\mathrm{pH} 2$ with sulphuric acid to minimise losses of $\mathrm{CH}_{4}$ through dissolution. Biogas composition was analysed each time a collection cylinder was emptied.

\subsection{Antifoam toxicity test}

Antifoam toxicity tests were carried out on seven antifoaming agents obtained from four companies. $20 \mathrm{~mL}$ aliquots of sieved digestate from Millbrook WWTP were dispensed into $119 \mathrm{~mL}$ serum bottles and antifoam was added at doses of $0.05,0.1,0.2,0.5$ or $1 \mathrm{~mL} \mathrm{~L}^{-1}$ digestate; controls with no antifoam added were also prepared. The headspace of each serum bottle was then flushed with an 80:20\% v/v mix of $\mathrm{N}_{2}: \mathrm{CO}_{2}$ (BOC, UK) and the bottle sealed using a crimp cap with a PTFE coated silicone septa. The serum bottles were placed in an incubator (Hybaid Maxi 14, Thermo Scientific, UK) at $37^{\circ} \mathrm{C}$ without shaking, operated under batch conditions. Tests were carried out in triplicate in three separate batches (A, B and C). Pressure was measured using a Digitron 2025P absolute pressure meter (Electron Technology, UK). Pressure was measured approximately 2, 4, 22, 28 and 46 hours from the start of the test, then daily over the rest of a 21-day test period. Headspace biogas volumes were calculated according to Eq. 1.

$$
\text { Biogas volume }(m L)=\frac{\left(P \times \operatorname{Vol} \times V_{m}\right)}{(R \times T)}
$$

Where $P$ = serum bottle headspace pressure $(\mathrm{kPa}), \mathrm{Vol}=$ serum bottle headspace volume in $\mathrm{mL}, V_{m}=$ molar volume of an ideal gas (taken as $22.414 \mathrm{~L} \mathrm{~mol}^{-1}$ ), $R=$ ideal gas constant (taken as $8.3145 \mathrm{~m}^{3} \mathrm{~Pa} \mathrm{~K}^{-1} \mathrm{~mol}^{-1}$ ) and $\mathrm{T}=$ incubation temperature $(\mathrm{K})$. Net biogas production for the sample was calculated by subtracting the average gas production of the controls over the same period.

\subsection{Semi-continuous digestion experiments}

Experiments on the effect of OLR, TE addition and feedstock dilution were carried out in ten mesophilic continuously-stirred tank reactor (CSTR) digesters. Each digester had a 5-L capacity with a 4-L working volume and was constructed of PVC tube with gas-tight top and bottom plates. The top plate was fitted with a gas outlet, a feed port sealed with a rubber bung, and a draught-tube liquid seal through which an asymmetric bar stirrer was inserted with a 40 rpm motor mounted directly on the top plate. Temperature was maintained at $37 \pm 0.5^{\circ} \mathrm{C}$ by water circulating through an external heating coil. Semi-continuous operation was achieved by adding feed once a day via the port in the top plate, and removing digestate through an outlet port in the base plate to maintain a constant volume. The configuration of the digesters used in this study was the same as that shown in Suhartini et al. (2014). 
Samples for analysis of digestate properties and biogas composition were taken at least weekly throughout the operating periods. The digesters were connected to tipping-bucket gas counters with continuous data logging. Calibration of gas counters was checked weekly by collecting the gas in a Tedlar bag (SKC Ltd, Blandford Forum, UK): the volume was then measured in a weight-type water displacement gasometer as described by Walker et al. (2009). All gas volumes are reported as dry biogas at a standard temperature and pressure of $0{ }^{\circ} \mathrm{C}$, $101.325 \mathrm{kPa}$.

The experimental design is summarised in Table 1. Four pairs of duplicate digesters (D18) were run for at least 3 hydraulic retention times (HRT) at OLR of 2, 3, 4, and 5 g VS L-1 day $^{-1}$. All digesters were initially fed at an OLR of $2 \mathrm{~g} \mathrm{VS} \mathrm{L}^{-1}$ day $^{-1}$, which was gradually raised to the target OLRs of $3 \mathrm{~g} \mathrm{VS} \mathrm{L}^{-1}$ day $^{-1}$ (D3\&4) by day 36, $4 \mathrm{~g} \mathrm{VS} \mathrm{L}^{-1}$ day $^{-1}$ (D5\&6) by day 71, and $5 \mathrm{~g} \mathrm{VS} \mathrm{L}^{-1}$ day $^{-1}$ (D7\&8) by day 162. Another pair of duplicate digesters (D9\&10) was started on day 50 using Millbrook inoculum and operated in the same way as D3\&4 at an OLR of $3 \mathrm{~g} \mathrm{VS} \mathrm{L}^{-1}$ day $^{-1}$ but with TE addition. A heater failure caused operational problems between days 80-90 and feeding was therefore stopped from day 85-90. Once the heater had been repaired, feeding was gradually restored to the previous OLR over a period of 20 days to avoid causing a shock to the digesters.

After the trial at OLR $4 \mathrm{~g} \mathrm{VS} \mathrm{L}^{-1}$ day $^{-1}$ was completed on day 320, this pair of digesters (D5\&6) was then operated at a working volume of $3 \mathrm{~L}$ and an OLR of $4 \mathrm{~g} \mathrm{VS} \mathrm{L}^{-1}$ day $^{-1}$ for 127 days, with the SBP feedstock diluted with tap water at a 1:1 weight ratio and with TE supplementation as for D9\&10.

Two 2-L CSTR digesters of the same design as the 5-L digesters above were operated at 1-L working volume to see if foaming could be eliminated by the use of an antifoaming agent (J-QUELL 19, J1 Technologies, Manchester, UK). Inoculum was obtained from one of the 5$\mathrm{L}$ digesters fed at OLR $5 \mathrm{~g}$ VS L ${ }^{-1}$ day $^{-1}$ (D8). The 2-L digesters were fed at OLR $5 \mathrm{~g} \mathrm{VS} \mathrm{L}{ }^{-1}$ day $^{-1}$, one without antifoam addition (D11) and the other with (D12). The height of foam in the digester above the original liquid surface was recorded, and antifoam was added periodically to reduce the foam volume when the level reached $4 \mathrm{~cm}$ from the top of the digester, equivalent to a $67.5 \%$ bed expansion. This experiment ran for 147 days.

\subsection{Analytical methods}

Total solids (TS) and volatile solids (VS) content were measured using Standard Method $2540 \mathrm{G}$ (APHA, 2005). pH was measured using a combination glass electrode calibrated in buffers at $\mathrm{pH} 4,7$ and 9 . Alkalinity was measured by titration with $0.25 \mathrm{~N} \mathrm{H}_{2} \mathrm{SO}_{4}$ to endpoints of pH 5.7 and 4.3 to allow determination of total (TA), partial (PA) and Intermediate (IA) alkalinity (Ripley et al., 1986). Total ammonia nitrogen (TAN) was determined using Kjeltech block digestion and steam distillation units (Foss Ltd, Warrington, UK) according to the manufacturer's instructions. Volatile fatty acids (VFA) were quantified in a Shimazdu GC2010 gas chromatograph (Shimadzu, Milton Keynes, UK), using a flame ionization detector and a capillary column type SGE BP-21. Biogas composition was determined using a Varian star $3400 \mathrm{CX}$ Gas Chromatograph with a standard gas of $65 \% \mathrm{CH}_{4}$ and $35 \% \mathrm{CO}_{2}$ (v/v) (BOC, UK). Scanning Electron Microscopy (SEM) was carried out using a FEI Quanta 200 scanning electron microscope, with the samples prepared as described in Suhartini et al. (2014).

Antifoam activity was measured using a de-foaming test method adapted from Denkov et al. (2002). $100 \mathrm{~mL}$ of surfactant solution (Sodium lauryl sulphate, $1 \% \mathrm{w} / \mathrm{v}$ ) was placed in a $300 \mathrm{~mL}$ graduated glass cylinder of $5 \mathrm{~cm}$ diameter. Antifoam was then added at dose of 0.5 $\mathrm{mL} \mathrm{L}^{-1}$. The cylinder was tightly plugged, and foam was generated by shaking 10 times along a vertical axis. Initial foam height was recorded, then foam height was recorded at 1-minute intervals for 6 minutes or until no foam remained (i.e. liquid surface). Foam volume was 
calculated by subtracting the volume of medium from the total volume (foam plus medium) in the cylinder. Tests were performed in duplicate.

VS destruction was calculated on a weekly basis using a mass balance approach, based on the quantities of feed added, digestate removed, and biogas produced by the digester. The mass of biogas removed was calculated from the average dry biogas volume and composition, with $\% \mathrm{CH}_{4}+\% \mathrm{CO}_{2}$ normalised to $100 \%$ (i.e. other gases assumed negligible), according to Eq.2.

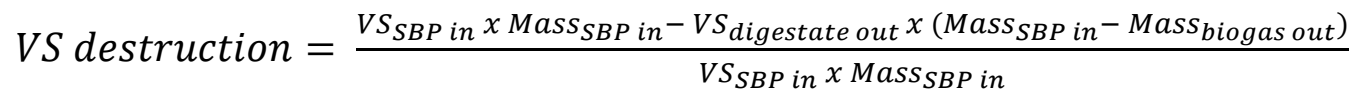

Where VS = VS content in $\mathrm{mg} \mathrm{kg}^{-1}$ wet weight (WW), Mass = mass in $\mathrm{kg} \mathrm{WW}$, and the suffices 'in' and 'out' refer to material added to or removed from the digester.

\section{Results and Discussion}

\subsection{BMP test}

The BMP value for the SBP was $0.321 \pm 0.03 \mathrm{~L} \mathrm{CH}_{4} \mathrm{~g}^{-1} \mathrm{VS}$. This is within the range of reported values for SBP of 0.294-0.385 $\mathrm{L} \mathrm{CH}_{4} \mathrm{~g}^{-1}$ VS (Alkaya and Demirer, 2011), and is fairly typical of crop and agro-waste substrates with a high cellulose content and relatively low lignin. Based on a higher heat value for methane of $39.84 \mathrm{MJ} \mathrm{m}^{-3}$, the BMP value represents a conversion efficiency of approximately $80 \%$ of the substrate calorific value. Results of the BMP testing are presented in more detail in the Supplementary Materials.

\subsection{Effect of OLR on digestion performance}

Performance in the periods leading up to and at the target OLR is shown in Fig.1, with average values for key parameters during steady-state or pseudo steady-state operation at the end of 3 HRT given in Table 2. Values for OLR $5 \mathrm{~g} \mathrm{VS} \mathrm{L}^{-1}$ day $^{-1}$ are represented by digester D8 only since the duplicate D7 failed before 3 HRT due to foaming problems, as discussed below.

At OLR $2 \mathrm{~g} \mathrm{VS} \mathrm{L}^{-1}$ day $^{-1}$ (D1\&2) the average steady-state volumetric biogas and volumetric methane production (Fig.1a) were $1.26 \mathrm{~L} \mathrm{~L}^{-1}$ day $^{-1}$ and $0.64 \mathrm{~L} \mathrm{CH}_{4} \mathrm{~L}^{-1}$ day $^{-1}$ while specific methane production (Fig. 1b) was $0.321 \mathrm{~L} \mathrm{CH}_{4} \mathrm{~g}^{-1} \mathrm{VS}$, similar to that obtained in the BMP test. At higher OLRs average specific methane production fell slightly to $\sim 0.30 \mathrm{~L} \mathrm{CH}_{4}$

$\mathrm{g}^{-1}$ VS: t-testing of the data used in Table 2 indicated this difference was significant $(\mathrm{p}<0.005)$. As expected, there was a clear increase in average volumetric biogas production from 1.26 up to $2.93 \mathrm{~L} \mathrm{~L}^{-1}$ day $^{-1}$ at OLR $5 \mathrm{~g} \mathrm{VS} \mathrm{L}^{-1}$ day $^{-1}\left(\mathrm{n}=7, \mathrm{R}^{2}=0.9968, \mathrm{p}<1 \times 10^{-7}\right)$ and in volumetric methane production from 0.64 to up $1.49 \mathrm{~L} \mathrm{CH}_{4} \mathrm{~L}^{-1} \mathrm{day}^{-1}\left(\mathrm{n}=7, \mathrm{R}^{2}=0.9976\right.$, $\mathrm{p}<1 \times 10^{-7}$ ) (Fig.1c). The temporary fall in gas production after day 80 (Fig. 1a and b) was due to the temperature drop caused by heater failure, and the subsequent gradual restoration of OLR.

At OLR $2 \mathrm{~g} \mathrm{VS} \mathrm{L}^{-1}$ day $^{-1}$ (D1\&2), there was a gradual rise in TA through the experimental period (Fig. 1d), from $\sim 12 \mathrm{~g} \mathrm{CaCO}_{3} \mathrm{~kg}^{-1} \mathrm{WW}$ of digestate to an average value of $\sim 18.7 \mathrm{~g} \mathrm{CaCO}_{3} \mathrm{~kg}^{-1} \mathrm{WW}$. This corresponded to an increase in TAN (Fig. 1e), which fell slightly during the disturbance associated with the heater failure but reached $\sim 2.1 \mathrm{~g} \mathrm{~N} \mathrm{~kg}^{-1}$ WW by the end of the run. In the digesters fed at OLR $3 \mathrm{~g} \mathrm{VS} \mathrm{L}^{-1} \mathrm{day}^{-1}$ (D3\&4), the final TA and TAN concentrations were slightly lower than at OLR $2 \mathrm{~g} \mathrm{VS} \mathrm{L}^{-1}$ day $^{-1}$, at average values of $\sim 16.4 \mathrm{~g} \mathrm{CaCO}_{3} \mathrm{~kg}^{-1} \mathrm{WW}$ and $\sim 1.6 \mathrm{~g} \mathrm{~N} \mathrm{~kg}^{-1} \mathrm{WW}$ respectively. Increases in OLR to 4 (D5\&6) and $5 \mathrm{~g} \mathrm{VS} \mathrm{L}^{-1}$ day $^{-1}$ (D7\&8) resulted in decreases in TA to average values of 15.6 and $\sim 13.7 \mathrm{~g} \mathrm{CaCO}_{3} \mathrm{~kg}^{-1} \mathrm{WW}$, respectively. Similarly, TAN concentrations decreased to average values of $\sim 1.4 \mathrm{~g} \mathrm{~N} \mathrm{~kg}^{-1} \mathrm{WW}$ and $\sim 1.1 \mathrm{~g} \mathrm{~N} \mathrm{~kg}^{-1} \mathrm{WW}$, respectively. The relationships 
between OLR and average steady-state values of TA and TAN are shown in Fig. $1 \mathrm{f}$ and were equivalent to a decrease of $\sim 1.7 \mathrm{~g} \mathrm{CaCO}_{3} \mathrm{~kg}^{-1}$ and $\sim 0.32 \mathrm{~g} \mathrm{~N} \mathrm{~kg}^{-1}$ per $\mathrm{g} \mathrm{VS} \mathrm{L}^{-1}$ day $^{-1}$ ( $\mathrm{n}=7$, $\mathrm{p}<0.005$ ), respectively. This change in TAN is probably due to the higher nitrogen demand for biomass growth at higher OLR, which in turn affects the TA. Lindorfer et al. (2012) also found that increases in OLR resulted in a decrease in TAN concentration, by 0.31 to $0.94 \mathrm{~g} \mathrm{~N}$ $\mathrm{kg}^{-1}$ per g VS L ${ }^{-1}$ day $^{-1}$.

The total VFA concentration in all sets of digesters fluctuated slightly during the experimental period with a slight upward trend at higher OLR (Table 2); under steady state conditions, however, the maximum total VFA concentration remained below $650 \mathrm{mg}$ COD L ${ }^{1}$ at all OLR. The IA/PA ratio for the digesters at OLR $2 \mathrm{~g} \mathrm{VS} \mathrm{L}^{-1}$ day $^{-1}$ (D1\&2) was 0.28, close to the value of 0.3 suggested by Ripley et al. (1986) as indicating good process stability. IA/PA ratios at higher OLR were slightly higher (Fig. 1g), indicating a potential decrease in process stability as also suggested by the rise in VFA values. The average $\mathrm{pH}$ value fell slightly with increasing OLR (Table 2) but remained between 7.2-7.5 (Fig. 1h), within an acceptable range for stable operation. Average VS destruction showed a decrease of approximately $2.4 \%$ per g VS L ${ }^{-1}$ day $^{-1}$ of OLR $(n=7, p<0.01)$ (Table 2), equivalent to an increase of around $0.1 \%$ per additional day of HRT. Taken together, these results indicate a minor reduction in digestion performance and stability at with increasing OLR in the range tested.

The only significant problem encountered during this trial was the appearance of stable foam with bed expansion, which can cause severe problems in both large and small-scale operation. This occurred in digesters at OLR $3 \mathrm{~g} \mathrm{VS} \mathrm{L}^{-1}$ day $^{-1}$ or above but was more evident at higher OLR. Foaming in the digesters at OLR $5 \mathrm{~g} \mathrm{VS} \mathrm{L}^{-1}$ day $^{-1}$ (D7\&8) appeared after the initiation of this loading, and continuously worsened up to the end of 3 HRT. On day 164 the foaming resulted in blockage of the gas outlet tube in one of these digesters (D7), causing an increase in pressure and explosive loss of digestate. The results of this are discussed in more detail below. As a precaution the working volumes in the digesters at OLR 4 (D5\&6) and $5 \mathrm{~g}$ $V_{S} L^{-1}$ day $^{-1}$ (D7\&8) were reduced to 3 L from day 165 onwards to provide headspace capacity for foam, with a corresponding reduction in daily feed to maintain the previous OLR.

Fluorescence in-situ hybridisation (FISH) analysis was carried out on selected samples of digestate to identify the dominant microbial populations. Results are shown in Figure S2, S3 and S4 in the Supplementary Materials. Despite the use of enzyme, ultrasonic and mechanical pre-treatments in preparing the samples for FISH analysis, it proved very difficult to break up the extracellular polymeric substances forming the floc. No filamentous microorganisms were observed in fresh foaming digestate, indicating that these were not a cause of foaming in this case.

Brooks et al. (2008) carried out mesophilic SBP digestion at OLR from 1.08-7.95 g VS L${ }^{1}$ day $^{-1}$ and reported a similar specific methane production of around $0.31 \mathrm{~L} \mathrm{~g}^{-1}$ VS. Suhartini et al. (2014) also found foaming at higher OLR in SBP digestion, and the current results support the view that OLR is a major factor in the initiation and occurrence of foaming. In this study foam formation at higher OLR was associated with a slight increase in the total VFA concentration. This may partially support the work of He et al. (2018) who found that prior to a foaming incident there was a rapid accumulation of VFA, particularly propionic acid. In the current work, however, only minor increases in propionic acid were seen $(<100$ $\mathrm{mg} \mathrm{L}^{-1}$ ), and in general these were not strongly linked to foaming onset.

At the end of the digestion trial the residual biogas and methane production was monitored for digester D8 fed at OLR $5 \mathrm{~g} \mathrm{VS} \mathrm{L}^{-1}$ day $^{-1}$; the results are presented in the Supplementary Materials.

\subsubsection{Consequences of foaming-induced pressurisation and digestate loss}


As noted above, one digester (D7) suffered particularly severe foaming as the OLR increased to $5 \mathrm{~g} \mathrm{VS} \mathrm{L}^{-1}$ day $^{-1}$, leading to a loss of digestate. Although the daily feed was reduced in order to maintain the previous OLR, in the following period this digester began to develop signs of process imbalance (Fig. 2). It is possible this was caused by overloading: the revised OLR was based on the digestate volume remaining after the digestate loss, but the large quantity of entrained gas could have caused a reduction in the digestate density and relative mass, and therefore in the available microbial biomass. It has been noted on several occasions, however, that digester performance can be impaired after an explosion (unpublished data, Southampton). The reasons for this are unknown, but may be related to short-term changes in physical and/or chemical conditions within the digester during pressurisation (e.g. increased dissolution of $\mathrm{CO}_{2}$ ). According to Subramanian and Pagilla (2014), sudden changes in physio-chemical conditions may result in severe foam formation due to rapid release of $\mathrm{CO}_{2}$. The difference in solubility of $\mathrm{CH}_{4}$ and $\mathrm{CO}_{2}$, which varies with temperature and other factors, means that $\mathrm{CH}_{4}$ may become trapped as bubbles in the digestate, while $\mathrm{CO}_{2}$ may be dissolved as carbonic acid and $\mathrm{HCO}_{3}{ }^{-}$in the liquid phase.

The negative effect of foaming and/or loss of digestate in digester D7 was evident in increasing VFA concentrations from $~$ day 260, with an accompanying fall in $\mathrm{pH}$ to below 6.5 (Fig. 2a and b). In an attempt to correct this, feeding was reduced from day 274 and $20 \mathrm{~mL}$ of ammonium bicarbonate solution (1 M) was added on days 279, 282 and 291 to raise the $\mathrm{pH}$. This was only partially successful, despite an increase in TA to $19 \mathrm{~g} \mathrm{CaCO}_{3} \mathrm{~kg}^{-1}$ accompanied by a rise in TAN to $\sim 3 \mathrm{~g} \mathrm{~N} \mathrm{~kg}^{-1} \mathrm{WW}$ (Fig. $2 \mathrm{~b}$ and c). The process imbalance was also reflected in a dramatic increase in IA/PA ratio to above 6. By day 320 the total VFA concentration was $>22 \mathrm{~g} \mathrm{COD} \mathrm{L}^{-1}$, indicating a kinetic uncoupling between acid producers and consumers. This is supported by the concurrent reduction in biogas and methane production, which fell to $<0.1 \mathrm{~L} \mathrm{~g}^{-1} \mathrm{VS}$ and $<0.05 \mathrm{~L} \mathrm{CH}_{4} \mathrm{~g}^{-1} \mathrm{VS}$. While propionic acid accumulation was seen (Fig. 2a), however, this followed the increase in OLR and the appearance of foaming, rather than appearing to cause it.

\subsection{Effect of TE supplementation}

Some key performance parameters for the digesters at OLR $3 \mathrm{~g} \mathrm{VS} \mathrm{L}^{-1}$ day $^{-1}$ with and without TE supplementation is shown in Fig. 3 and Table 3. The pair of digesters with TE supplementation (D9\&10) appeared to show slightly higher gas yields and a lower IA/PA ratio than those at the same OLR but without TE (D3\&4); but these differences were minor, and could not be shown to be statistically significant due to the small number of replicates. Despite the low TE concentrations in the feedstock (Suhartini et al., 2014), as can be seen from Fig. 3 there was very little difference with respect to TAN, pH, or TA between the digesters with and without TE supplementation. The average values for IA/PA ratio were slightly lower in the digesters with TE supplementation (Tables 2 and 3), although both sets were clearly within the stable operational range.

The only noticeable difference between the two sets of digesters was that those without TE addition experienced foaming, which began several weeks before the completion of 3 HRT; while no foaming was observed in the TE supplemented digesters. Moestedt et al. (2016) noted a major reduction in digestate viscosity, which is linked to foaming and bed expansion, following the addition of selected TE. Karlsson et al. (2012) also noted TE addition reduced the occurrence of foaming in digesters processing food waste, but could not eliminate it entirely. Suhartini et al. (2014) found, however, that foaming still occurred in SBP digesters at OLR 4 and $5 \mathrm{~g} \mathrm{VS} \mathrm{L}^{-1}$ day $^{-1}$ despite TE addition. These results thus indicate that TE addition may be more effective at moderate OLR, but there is considerable scope for further optimisation of TE dosing. 


\subsection{Effect of water dilution}

Fig. 4 presents the results for digester operation at OLR $4 \mathrm{~g} \mathrm{VS} \mathrm{L}^{-1}$ day ${ }^{-1}$ with feedstock dilution (D5\&6). Specific biogas production decreased from an average of $0.585 \mathrm{~L} \mathrm{~g}^{-1} \mathrm{VS}$ before dilution started to around $0.487 \mathrm{~L} \mathrm{~g}^{-1}$ VS (average for the duplicate digesters) by the end of the run (Table 3). A similar trend was observed in specific methane production, which fell from an average of 0.298 to $0.245 \mathrm{~L} \mathrm{CH}_{4} \mathrm{~g}^{-1} \mathrm{VS}$ (Fig. 4a). Average volumetric biogas and methane yields, although varying slightly during the experimental period, also showed a

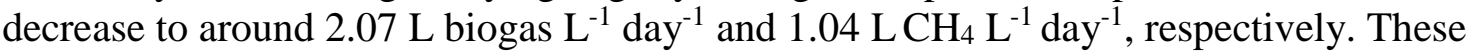
results were well below those at the same OLR in the same digesters without dilution, which had average volumetric biogas and methane productions of $2.35 \mathrm{~L} \mathrm{~L}^{-1}$ day ${ }^{-1}$ and $1.21 \mathrm{~L} \mathrm{CH}_{4} \mathrm{~L}^{-}$ ${ }^{1}$ day $^{-1}$, respectively (Table 2, Fig. $1 \mathrm{a}$ and b). The dilution also halved the HRT, however, from about 56 to about 28 days. The relative extent to which gas production was affected by this reduced HRT, as opposed to any washout of useful nutrients, is unknown.

TAN concentration and TA decreased continuously during the experimental period (Fig. 4b and c), from $\sim 1.4$ to $\sim 0.7 \mathrm{~g} \mathrm{~N} \mathrm{~kg}^{-1} \mathrm{WW}$ and from $\sim 16$ to $\sim 7 \mathrm{~g} \mathrm{CaCO}_{3} \mathrm{~kg}^{-1} \mathrm{WW}$ respectively. Although these values remained within recommended ranges, dilution evidently reduced the buffering capacity. This was accompanied by a decrease in $\mathrm{pH}$ throughout the experimental period from 7.45 to 7.00 (Fig. 4d), although again the values remained in an acceptable range. Total VFA concentrations varied slightly (Fig. 4e), but from day 22 onwards the average total VFA concentration in both D5 and D6 was less than $130 \mathrm{mg}$ COD $\mathrm{L}^{-1}$. The IA/PA ratio at start-up was relatively high at around 0.7 and increased continuously to above 1.0 at the end of experiment (Fig. 4f), indicating a growing degree of process imbalance.

These results indicated that feedstock dilution had a slight adverse effect on the stability and performance of the digesters. This was probably due to reductions in both HRT and buffering capacity, leading to a fall in $\mathrm{pH}$ and a rise in IA/PA ratio. From start-up to day 107 no significant foaming was noted in either digester. From on day 108, however, foaming occurred in both digesters and continued up to the end of the experimental run (day 123). This result is in contrast to the findings of studies on a range of feedstocks, where dilution has been reported as an effective strategy for foaming control (Demirel and Scherer, 2009; Kougias et al., 2014b; Moeller and Görsch, 2015; Lindorfer and Demmig, 2016). In the case of SBP, dilution sufficient to affect digestion performance was still unable to prevent the occurrence of foaming, indicating that the success of this strategy is feedstock-specific.

\subsection{Effects of antifoam addition}

\subsubsection{De-foaming tests}

In de-foaming tests, foam volumes generated after the addition of antifoams were several times less than in the control sample. After 6 minutes of observation the volume of the control sample remained the same; whereas with $0.5 \mathrm{~mL} \mathrm{~L}^{-1}$ of antifoam the foam volume was reduced within 60 seconds in all cases. Foam volume reductions are shown in Table 4 and in most cases the reduction efficiency was $70 \%$ or more. KemFoamX 2125, which is a water based fatty alcohol emulsion (no silicone), gave a slightly lower reduction at $63 \%$, while JQUELL 19 (mineral oil) was marginally the most effective. The minor differences noted in foam reduction efficiency were probably due to the physico-chemical characteristics and properties of the antifoams, as noted by Denkov and Marinova (2006) and Kougias et al. (2013b). Denkov and Marinova (2006) found that antifoam containing silicone oil was able greatly to reduce foaming occurrence, and the addition of silica improved this further. Kougias et al. (2013b) found that antifoams containing natural oil (e.g. rapeseed oil, sunflower oil), Long Chain Fatty Acids (LCFA) (e.g. oleic acid and octanoic acid), esters (tributylphosphate), and commercial antifoams (natural fatty acids - Struktol SB 2080) were 
the most effective compounds for suppressing foam in raw and digested cattle manure samples, with reduction efficiencies of $89-100 \%$. Other antifoams containing silicone emulsion (Struktol SB 2113 Dimethylpolysiloxane), alcohol (ethanol), and salts (e.g. polyaluminium chloride, calcium chloride dihydrate and magnesium chloride hexahydrate) had foam reduction efficiencies of less than 30\% (Denkov and Marinova, 2006).

\subsubsection{Antifoam toxicity assay}

Average net biogas production from all of the digestate samples in the antifoam assay is shown in Fig. 5 together with the biogas production from the triplicate controls. Apart from some variation for set $\mathrm{A}$ in the second half of the run (Fig. 5a), the controls for each set showed very good agreement, giving confidence in the overall biogas results.

In general, it can be seen that all of the sample sets with antifoam added in the range of 0.05- $0.2 \mathrm{~mL} \mathrm{~L}^{-1}$ digestate produced more biogas than their respective control samples. Of the three silicone emulsions tested (AF 530, BC 86/103 and KemFoamX 2816), AF 530 showed a small net increase in biogas yield with increasing antifoam dosage from $0.05-0.2 \mathrm{~mL} \mathrm{~L}^{-1}$ digestate, all of which was produced within the first 75 hours of the test (Fig. 5b). At a dosage of $1.0 \mathrm{~mL} \mathrm{~L}^{-1}$, however, there was an initial peak in cumulative biogas production; but the cumulative net total started to fall after 116 hours, leading to a negative value at the end of the experiment. Antifoam BC 86/103 at a dose of $0.5 \mathrm{~mL} \mathrm{~L}^{-1}$ and $1.0 \mathrm{~m} \mathrm{~mL} \mathrm{~L}^{-1}$ caused severe inhibition. This reduced to mild inhibition at $0.2 \mathrm{~mL} \mathrm{~L}^{-1}$, no inhibition at $0.1 \mathrm{~mL} \mathrm{~L}^{-1}$ and a small increase in net biogas production at $0.05 \mathrm{~mL} \mathrm{~L}^{-1}$ (Fig. 5c). The addition of KemFoamX 2816 at doses above $0.5 \mathrm{~mL} \mathrm{~L}^{-1}$ resulted in negative net biogas production at the beginning of the test then a small increase some days later (Fig. 5d).

Addition of KemFoamX 2125 (water-based fatty alcohol) at doses above $0.5 \mathrm{~mL} \mathrm{~L}^{-1}$ resulted in negative net biogas production. At doses of $0.05-0.2 \mathrm{~mL} \mathrm{~L}^{-1}$, net production was negative at the beginning of the test, but gave a small positive value later (Fig. 5e). For KemFoamX 2500 (oil-free ester) and KemFoamX 2641 (oil-based) similar trends were observed (Fig. 5f and g), although for KemFoamX 2641 the final net gas production was positive in all cases. In contrast J-QUELL 19 showed little or no effect on gas production throughout the test at all concentrations tested and no sign of inhibition was observed (Fig. 5h).

The above results demonstrated that the inoculum was active and contained readily biodegradable material, but the addition of certain antifoams particularly at dosages of $0.5 \mathrm{~mL}$ $\mathrm{L}^{-1}$ or more could inhibit gas production. J-QUELL 19 appeared to cause the least disturbance in batch testing. Based on this and the results of the de-foaming assay, J-QUELL 19 was selected for further testing in a semi-continuous trial to determine its effect when used to minimise foaming in long-term operation.

\subsubsection{Digestion performance after antifoam addition}

Based on the serum-bottle test results it was decided to use an initial antifoam dose of 0.1 $\mathrm{mL} \mathrm{L}^{-1}$ digestate. On day 1 , antifoam was added to D12, but had no significant effect on reducing the foaming. Antifoam addition was then gradually increased as needed.

It was found that to reduce the level of foam in D12 a very high dose of antifoam was required ( $1 \mathrm{~mL} \mathrm{~L}^{-1}$, compared to typical values of $\leq 0.1 \mathrm{~mL} \mathrm{~L}^{-1}$ in industrial practice). This dose had to be repeated at intervals of 2 weeks. After four treatments (8 weeks in total) no further antifoam addition was needed; but over the following month VFA concentrations in digester D12 rose, and the pH fell to 6.2 (Fig. 6a and b). On day 106, $20 \mathrm{~mL}$ of ammonium bicarbonate solution (1 M) was added to boost the buffering capacity (Fig. 6c) and increase the pH. This did not solve the problem, however, and the $\mathrm{pH}$ again fell below 6.5, resulting in failure of the digestion. The digester without antifoam addition (D11) showed no sign of VFA accumulation 
or other performance instability. Volumetric biogas and methane yields in D11 remained constant at $2.83 \mathrm{~L} \mathrm{~L}^{-1}$ day $^{-1}$ and $1.43 \mathrm{~L} \mathrm{CH}_{4} \mathrm{~L}^{-1}$ day $^{-1}$ (Fig. $6 \mathrm{~d}$ ). These values were slightly lower than those obtained in the previous semi-continuous trial at the same OLR (Table 2).

Figure S5a in the Supplementary Materials shows foam at the surface of the SBP digestate in the untreated digester (D11) sampled on day 180. As can be seen, large numbers of tiny gas bubbles appear to be entrapped in the digestate. This was not limited to the surface, but was homogeneous throughout with no apparent interface between a foam layer and the bulk digestate. As OLR increases, the rate of biogas generation may exceed the rate of escape causing expansion of the matrix. Bartek et al. (2015) suggested rapid volume expansion, associated with blocking of gas outlets and digestate loss, occurs when bubbles trapped in suspension grow sufficiently to overcome the digestate yield stress. Figure S5b in the supplementary materials shows an SEM image of a sample of foaming digestate. The structure is similar to SEM images of digestate when not foaming (Suhartini et al., 2014), suggesting that foaming is more affected by the properties of the liquid than the solid phase. Moeller et al. (2015a) investigated the chemical composition of foam in digesters fed on sugar beet silage and noted high carbohydrate concentrations in the foam phase.

The above results confirm the importance of the choice of antifoam, due to its impact on both the physico-chemical properties and the microbial activity of the medium (or inoculum). Routledge et al. (2011) compared the performance of five different types of antifoam, including Struktol J673A (oil based), antifoam A and C (silicone emulsion), Schell and Schelinger's Struktol SB2121 (polyalkylene glycol) and Fluka P2000 (a polypropylene glycol) at dosages of $0.1-1.0 \%(\mathrm{v} / \mathrm{v})$, in the production of green fluorescent protein (GFP) from recombinant Pichia pastoris. The addition of oil-based antifoam (Struktol J673A) had a positive effect in enhancing the amount of GFP secreted into the medium from $246 \mu \mathrm{g}$ GFP (control) to $394 \mu \mathrm{g}$ GFP.

Moeller et al. (2010) also noted that antifoaming agents can influence the anaerobic biological process, while Moeller et al. (2018) stated that antifoam can be toxic to the microorganisms and also change operational parameters such as digester $\mathrm{pH}$. The addition of silicon-based antifoam agents may also result in siloxanes in the biogas, with the potential to cause damage in gas engines through the deposition of silicon dioxide particles (Dewil et al., 2006).

In the present case, addition of the selected agent was very effective in reducing the foam; but this was only a short-term benefit, with longer exposure having a toxic effect. Although JQUELL 19 did not enhance biogas production in the toxicity assay, indicating it was not readily degradable in the system, there was nothing to suggest any adverse effect. This indicates that the technique used is not effective as a screening test, and alternative assays need to be developed that provide better insight on inhibitory properties. It was also noted that the SBP digestate foam was strongly resistant to the antifoam agent, with a very high dose of $1 \mathrm{~mL} \mathrm{~L}^{-1}$ of digestate required to reduce foaming.

Addition of antifoam costs money and, while it may be effective and acceptable for shortterm or emergency use, it is not a favoured approach for the longer term. This is due both to the cost, and to the risk of inhibitory effects on the microbial consortia in anaerobic digesters. The approach of TE addition appeared promising at moderate OLR (OLR $3 \mathrm{~g} \mathrm{VS} \mathrm{L}^{-1}$ day $^{-1}$ or less) but again has cost implications and further optimisation of dosages is needed.

\section{Conclusions}

The OLR had a strong influence on digestion performance and foaming occurrence in mesophilic AD of SBP. Volumetric biogas and methane productivity increased approximately linearly with increasing OLR, but foam formation was evident at OLR of $3 \mathrm{~g} \mathrm{VS} \mathrm{L}^{-1}$ day $^{-1}$ and above, and was accompanied by a slight reduction in specific methane productivity and 
indications of reduced operational stability. At OLR $3 \mathrm{~g} \mathrm{VS} \mathrm{L}{ }^{-1}$ day $^{-1}$, dilution of the SBP feedstock with water $(1: 1 \mathrm{w} / \mathrm{w})$ did not prevent the occurrence of foaming, and had an adverse effect on performance in terms of biogas productivity. Addition of antifoams in batch defoaming activity tests successfully reduced foam quantities by around $70 \%$ for all types of antifoam tested. In batch toxicity assays, most of the antifoams tested showed a small enhancement of biogas production at dosages of up to $0.2 \mathrm{~mL} \mathrm{~L}^{-1}$, while some (e.g. water-based fatty alcohol and silicone emulsion) showed inhibitory effects at doses above $0.5 \mathrm{~mL} \mathrm{~L}^{-1}$. In semi-continuous digestion trials, antifoam addition was found to be necessary to control foaming at OLR $5 \mathrm{~g} \mathrm{VS} \mathrm{L}^{-1}$ day $^{-1}$, but the dose required was considerably higher than values typical of industrial use, and in the case of the selected antifoam led to inhibition of the digestion process. An improved toxicity screening test protocol is needed to take account of differences between batch and semi-continuous operation. TE supplementation was the most effective strategy tested for SBP, and appeared to be beneficial both in maintaining the digestion performance and in eliminating foaming.

\section{Conflicts of interest}

The authors declare no conflict of interest.

\section{Acknowledgements}

The authors would like to thank the Indonesian Government - Directorate General of Higher Education (DGHE) and Universitas Brawijaya - Indonesia for scholarship funding to support this research; and British Sugar PLC for the supply of materials and good advice.

\section{References}

Aboudi, K., Álvarez-Gallego, C.J., Romero-García, L.I., 2015. Semi-continuous anaerobic co-digestion of sugar beet byproduct and pig manure: effect of the organic loading rate (OLR) on process performance. Bioresour. Technol. 194, 283-290.

Aboudi, K., Álvarez-Gallego, C.J., Romero-García, L.I., 2016. Biomethanization of sugar beet byproduct by semi-continuous single digestion and co-digestion with cow manure. Bioresour. Technol. 200, 311-319.

Alfaro, N., Cano, R., Fdz-Polanco, F., 2014. Effect of thermal hydrolysis and ultrasounds pretreatments on foaming in anaerobic digesters. Bioresour. Technol. 170, 477-482.

Alkaya, E., Demirer, G.N., 2011. Anaerobic acidification of sugar-beet processing wastes: effect of operational parameters. Biomass Bioenergy. 35, 32 - 39.

APHA, 2005. Standard Methods for the Examination of Water and Wastewater, $21^{\text {st }}$ Ed. American Public Health Association, American Water Works Association, Water Environment Federation Washington, USA.

Banks, C.J., Zhang, Y., Jiang, Y., Heaven, S., 2012. Trace element requirements for stable food waste digestion at elevated ammonia concentrations. Bioresour. Technol. 104, 127135.

Bartek, N., Higgins, M.J., Murthy, S.N., Beightol, S., Peaslee, T., 2015. Causes and cures of rapid volume expansion in anaerobic digesters due to gas holdup, WEF/IWA Residuals and Biosolids 2015 Conference: The Next Generation of Science, Technology, and Management Walter E. Washington Convention Center, Washington D.C., 7 - 10 June 2015, pp. 1-15.

Borowski, S., Kucner, M., 2019. The use of sugar beet pulp stillage for co-digestion with sewage sludge and poultry manure. Waste Manage. Res. 1-8. 37(10), 1025-1032.

British Sugar, 2019. About sugar: Our co-products (animal feed). 
https://www.britishsugar.co.uk/about-sugar/co-products (Accessed on 8 January 2019).

Brooks, L., Parravicini, V., Svardal, K., Kroiss, H., Prendi, L., 2008. Biogas from sugar beet press pulp as substitute of fossil fuels in sugar beet factories. Water Sci. Technol. 58(7), 1497-1504.

Cooney, M., Maynard, N., Cannizzaro, C., Benemann, J., 2007. Two-phase anaerobic digestion for production of hydrogen-methane mixtures. Bioresour. Technol. 98, 26412651.

Defra, 2017. Agriculture in the United Kingdom 2017. https://assets.publishing.service.gov.uk/government/uploads/system/uploads/attachment_d ata/file/741062/AUK-2017-18sep18.pdf (Accessed 12 January 2018).

Demirel, B., Scherer, P., 2009. Bio-methanization of energy crops through mono-digestion for continuous production of renewable biogas. Renew. Energy 34(12), 2940-2945.

Demirel, B. and Scherer, P., 2011. Trace element requirements of agricultural biogas digesters during biological conversion of renewable biomass to methane. Biomass and Bioenergy, 35(3), 992-998.

Denkov, N.D., Marinova, K.G., 2006. Antifoam effects of solid particles, oil drops and oilsolid compounds in aqueous foams. In: Binks, B.P., Horozov, T.S., (Eds.), Colloidal Particles at Liquid Interfaces, Cambridge University Press, Cambridge, pp. 383-444.

Denkov, N.D., Tcholakova, S., Marinova, K.G., Hadjiiski, A., 2002. Role of oil spreading for the efficiency of mixed oil-solid antifoams. Langmuir. 18, 5810-5817.

Dewil, R., Appels, L., Baeyens, J., 2006. Energy use of biogas hampered by the presence of siloxanes. Energy Conver. Manage. 47(13), 1711-1722.

Fang, C., Boe, K., Angelidaki, I., 2011. Anaerobic co-digestion of by-products from sugar production with cow manure. Water Res. 45(11), 3473-3480.

Ganidi, N., Tyrrel, S., Cartmell, E., 2009. Anaerobic digestion foaming causes - A review. Bioresour. Technol. 100, 5546-5554.

Ganidi, N., Tyrrel, S., Cartmell, E., 2011. The effect of organic loading rate on foam initiation during mesophilic anaerobic digestion of municipal wastewater sludge. Bioresour. Technol. 102(12), 6637-6643.

He, Q., Li, L., Peng, S., Zhao, X., Qu, L., Wang, X., Peng, X., 2017. Foaming phenomenon in anaerobic digestion system treating food waste. China Environ. Sci. 37(3), 1040-1050.

Jiang, C., Qi, R., Hao, L., McIlroy, S.J., Nielsen, P.H., 2018. Monitoring foaming potential in anaerobic digesters. Waste Manage. 75, 280-288.

Karlsson, A., Einarsson, P., Schnürer, A., Sundberg, C., Ejlertsson, J., Svensson, B.H., 2012. Impact of trace element addition on degradation efficiency of volatile fatty acids, oleic acid and phenyl acetate and on microbial populations in a biogas digester. J. Biosci. Bioeng. 114(4), 446-452.

Kougias, P.G., Boe, K., Angelidaki, I., 2013a. Effect of organic loading rate and feedstock composition on foaming in manure-based biogas reactors. Bioresour. Technol. 144, 1-7.

Kougias, P.G., Tsapekos, P., Boe, K., Angelidaki, I., 2013b. Antifoaming effect of chemical compounds in manure biogas reactors. Water Res. 47(16), 6280-6288.

Kougias, P.G., De Francisci, D., Treu, L., Campanaro, S., Angelidaki, I., 2014a. Microbial analysis in biogas reactors suffering by foaming incidents. Bioresour. Technol. 167, 24-32.

Kougias, P.G., Boe, K., O-Thong, S., Kristensen, L.A., Angelidaki, I., 2014b. Anaerobic digestion foaming in full-scale biogas plants: a survey on causes and solutions. Water Sci. Technol. 69(4), 889-895.

Kougias, P.G., Boe, K., Tsapekos, P., Angelidaki, I., 2014c. Foam suppression in overloaded manure-based biogas reactors using antifoaming agents. Bioresour. Technol. 153, 198-205.

Kougias, P.G., Boe, K., Angelidaki, I., 2015a. Solutions for foaming problems in biogas reactors using natural oils or fatty acids as defoamers. Energy Fuel. 29(7), 4046-4051. 
Kougias, P.G., Boe, K., Einarsdottir, E.S., Angelidaki, I., 2015b. Counteracting foaming caused by lipids or proteins in biogas reactors using rapeseed oil or oleic acid as antifoaming agents. Water Res. 79, 119-127.

Lienen, T., Kleyböcker, A., Verstraete, W., Würdemann, H., 2014. Foam formation in a downstream digester of a cascade running full-scale biogas plant: influence of fat, oil and grease addition and abundance of the filamentous bacterium Microthrix parvicella. Bioresour. Technol. 153, 1-7.

Lindorfer, H., Ramhold, D. and Frauz, B., 2012. Nutrient and trace element supply in anaerobic digestion plants and effect of trace element application. Water Science and Technology, 66(9), pp.1923-1929.

Lindorfer, H., Demmig, C., 2016. Foam formation in biogas plants - a survey on causes and control strategies. Chem. Eng. Technol. 39(4), 620-626.

Moeller, L., Herbes, C., Müller, R.A., Zehnsdorf, A., 2010. Formation and removal of foam in the process of anaerobic digestion. Landtechnik. 65(3), 204 - 207.

Moeller, L., Goersch, K., Neuhaus, J., Zehnsdorf, A., Mueller, R.A., 2012a. Comparative review of foam formation in biogas plants and ruminant bloat. Energy, Sustain. Soc. 2(12), 1-9.

Moeller, L., Görsch, K., Müller, R.A., Zehnsdorf, A., 2012b. Formation and suppression of foam in biogas plants-practical experiences. Agric. Eng. 67(2), 110-113.

Moeller, L., Görsch, K., 2015. Foam formation in full-scale biogas plants processing biogenic waste. Energy, Sustain. Soc. 5(1), 1-16.

Moeller, L., Lehnig, M., Schenk, J., Zehnsdorf, A., 2015a. Foam formation in biogas plants caused by anaerobic digestion of sugar beet. Bioresour. Technol. 178, 270-277.

Moeller, L., Eismann, F., Wißmann, D., Nägele, H.-J., Zielonka, S., Müller, R.A., Zehnsdorf, A., 2015b. Innovative test method for the estimation of the foaming tendency of substrates for biogas plants. Waste Manage. 41, 39-49.

Moeller, L., Krieg, F., Zehnsdorf, A., Müller, R.A., 2016. How to avoid foam formation in biogas plants by coarse grain anaerobic digestion. Chem Eng. Technol. 39(4), 673-679.

Moeller, L., Zehnsdorf, A., 2017. Measures to prevent foam formation in the anaerobic digestion of sugar beet in biogas plants. Landtechnik. 72(1), 13-22.

Moeller, L., Zehnsdorf, A., Pokorná, D., Zábranská, J., 2018. Foam formation in anaerobic digester. In: Li, Y., Ge, X., (Eds.), Advance in Bioenergy, Vol. 3, Academic Press, London, pp.1-42.

Moestedt, J., Nordell, E., Shakeri, Y.S., Lundgren, J., Martí, M., Sundberg, C., Ejlertsson, J., Svensson, B.H., Björn, A., 2016. Effects of trace element addition on process stability during anaerobic co-digestion of OFMSW and slaughterhouse waste. Waste Manage. 47, 11-20.

Moestedt, J., Rönnberg, J., Nordell, E., 2017. The effect of different mesophilic temperatures during anaerobic digestion of sludge on the overall performance of a WWTP in Sweden. Water Sci. Technol. 76(12), 3213-3219.

Parawira, W., Read, J.S., Mattiasson, B., Björnsson, L., 2008. Energy production from agricultural residues: High methane yields in pilot-scale two-stage anaerobic digestion. Biomass Bioenergy. 32, 44-50.

Pognani, M., Scaglia, B., D'imporzano, G., Adani, F., 2017. Isolation and characterization of surface-active fractions responsible for foam formation during anaerobic digestion of municipal wastes. Environ. Progress Sustain. Energy. 36(2), 359-365.

Ripley, L.E., Boyle, W.C., Converse, J.C., 1986, Improved alkalimetric monitoring for anaerobic digestion of high-strength wastes. J. Water Pollut. Control Fed. 58(5), 406-411.

Routledge, S.J., Hewitt, C.J., Bora, N., Bill, R.M., 2011. Antifoam addition to shake flask cultures of recombinant Pichia pastoris increases yield. Microb. Cell Fact. 10(17), 1-12. 
Siebels, A.M., Long, S.C., 2013. Foaming phenomenon in bench-scale anaerobic digesters. Water Environ. Res. 85(4), 363-373.

Škrbić, B., Durišić-Mladenović, N., Mačvanin, N., 2010. Determination of metal contents in sugar beet (Beta vulgaris) and its products: empirical and chemometrical approach. Food Sci. Technol. Res. 16(2), 123-134.

Stoyanova, E., Forsthuber, B., Pohn, S., Schwarz, C., Fuchs, W., Bochmann, G., 2014 Reducing the risk of foaming and decreasing viscosity by two-stage anaerobic digestion of sugar beet pressed pulp. Biodegrad. 25(2), 277-289.

Subramanian, B., Miot, A., Jones, B., Klibert, C., Pagilla, K.R., 2015. A full-scale study of mixing and foaming in egg-shaped anaerobic digesters. Bioresour. Technol. 192, 461-470.

Subramanian, B., Pagilla, K.R., 2014. Anaerobic digester foaming in full-scale cylindrical digesters - effects of organic loading rate, feed characteristics, and mixing. Bioresour. Technol. 159, 182-192.

Suhartini, S., Heaven, S., Banks, C.J., 2014. Comparison of mesophilic and thermophilic anaerobic digestion of sugar beet pulp: Performance, dewaterability and foam control. Bioresour. Technol. 152, 202-211.

Van Weelden, M.B., Andersen, D.S., Kerr, B.J., Trabue, S.L., Pepple, L.M., 2016. Impact of fiber source and feed particle size on swine manure properties related to spontaneous foam formation during anaerobic decomposition. Bioresour. Technol. 202, 84-92.

Walker, M., Zhang, Y., Heaven, S., Banks, C.J., 2009. Potential errors in the quantitative evaluation of biogas production an anaerobic digestion processes. Bioresour. Technol. 100, 6339-6346.

Xu, F., Li, Y., Ge, X., Yang, L., Li, Y., 2018. Anaerobic digestion of food waste-challenges and opportunities. Bioresour. Technol. 247, 1047-1058. 


\section{Figures}
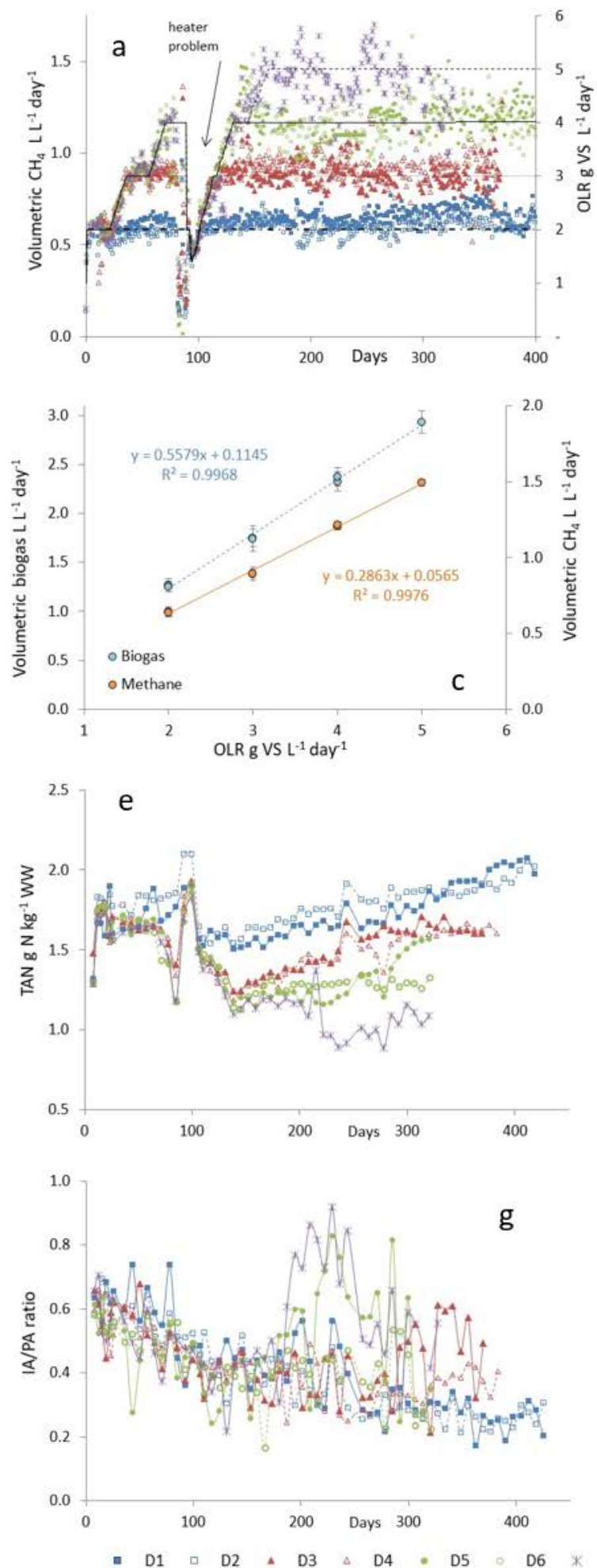
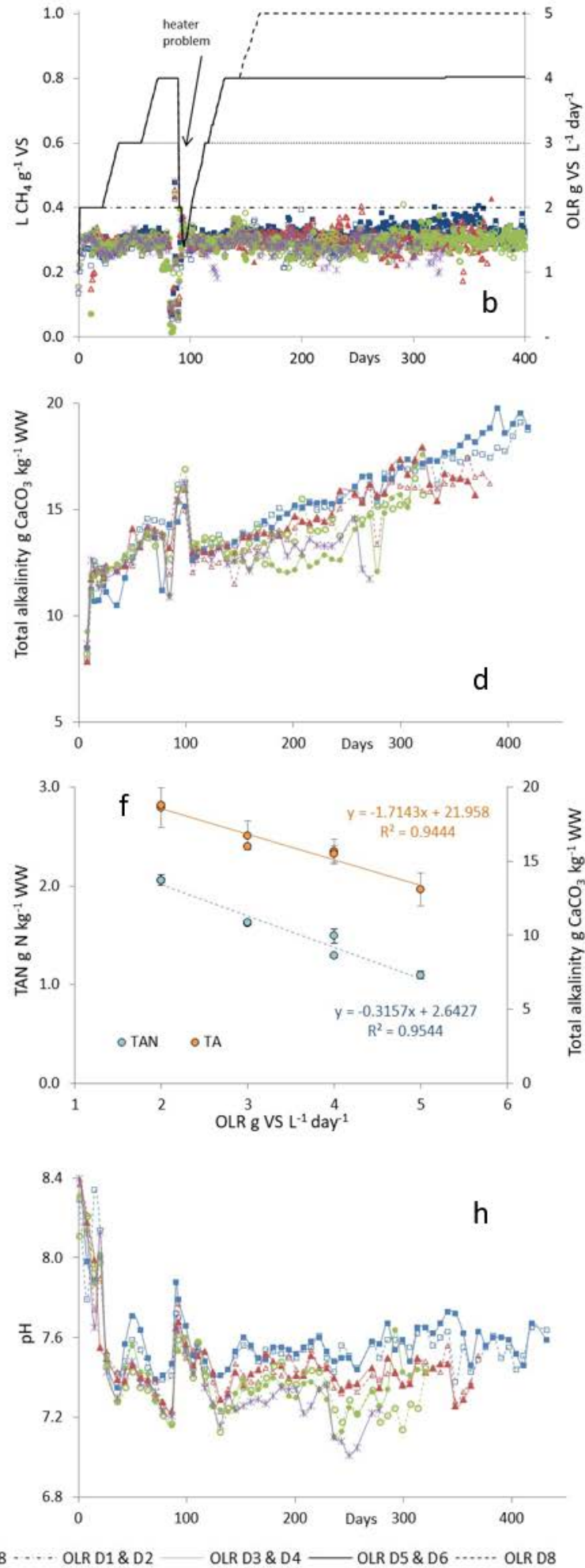

Fig. 1. Volumetric and specific methane production, OLR, TAN, TA, total VFA, IA/PA ratio and $\mathrm{pH}$ during anaerobic digestion of SBP at OLR of 2-5 $\mathrm{g} \mathrm{VS} \mathrm{L}^{-1}$ day $^{-1}$. Values shown are for duplicate reactors at each OLR apart from OLR 5 (D8 only). 

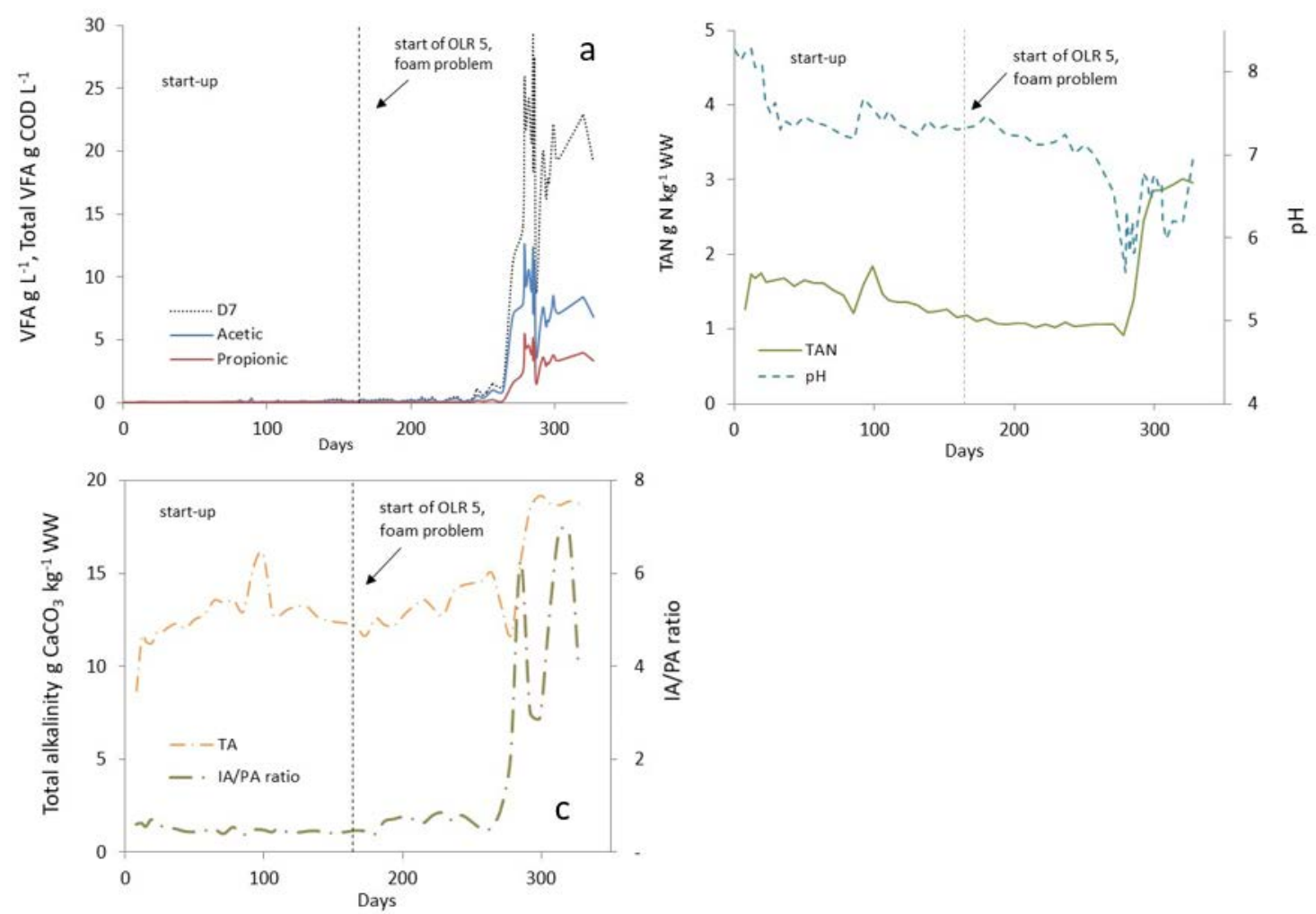

Fig. 2. Total VFA, TAN, pH, TA and IA/PA ratio for digester D7 at OLR $5 \mathrm{~g} \mathrm{VS} \mathrm{L}^{-1}$ day $^{-1}$ which experienced loss of digestate due to foaming on day 164.
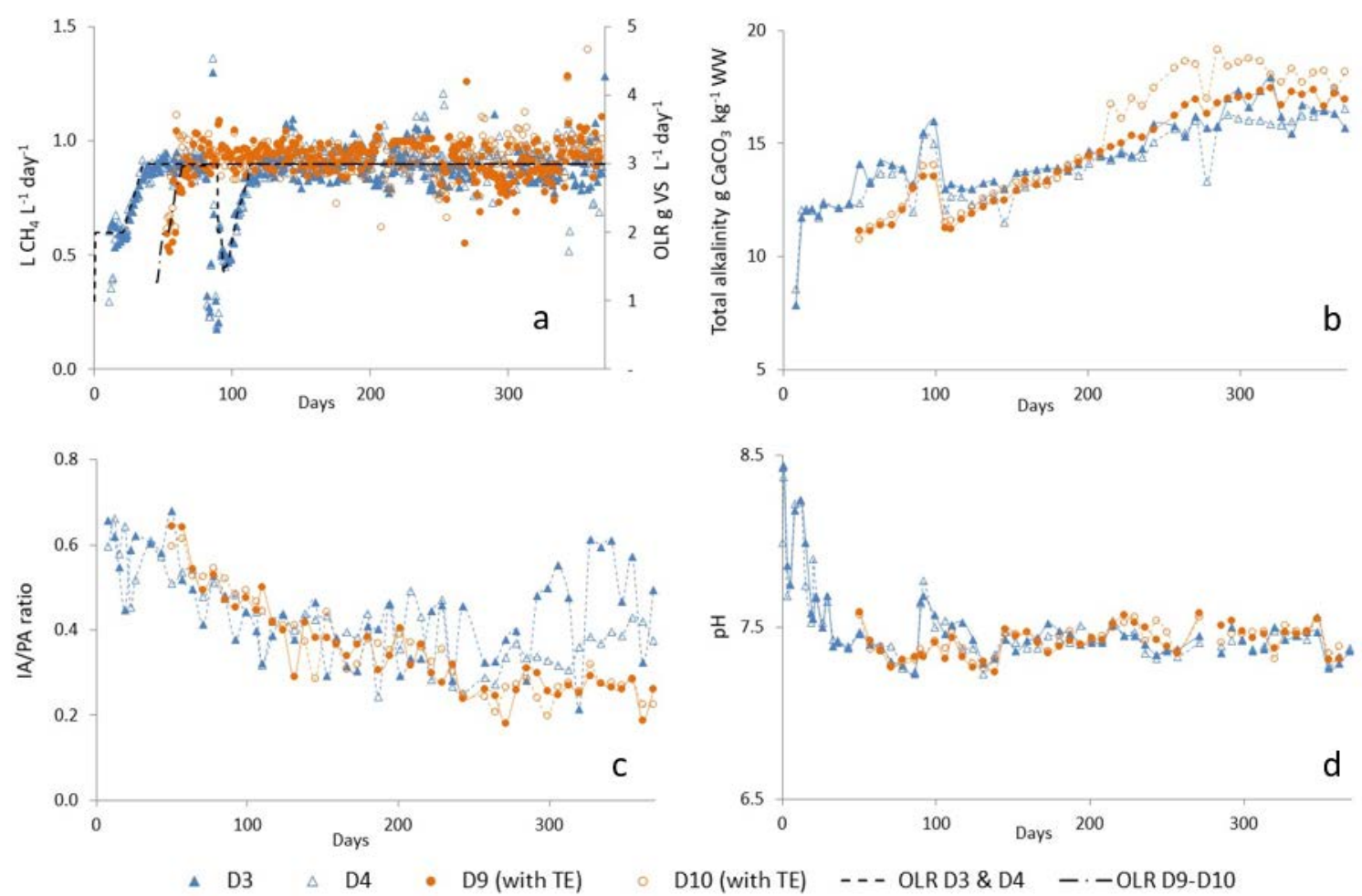

Fig. 3. Volumetric methane production, OLR, TA, IA/PA ratio and $\mathrm{pH}$ during anaerobic digestion of SBP at OLR $3 \mathrm{~g} \mathrm{VS} \mathrm{L}^{-1}$ day $^{-1}$ with (D9\&10) and without (D3\&4) TE supplementation. 

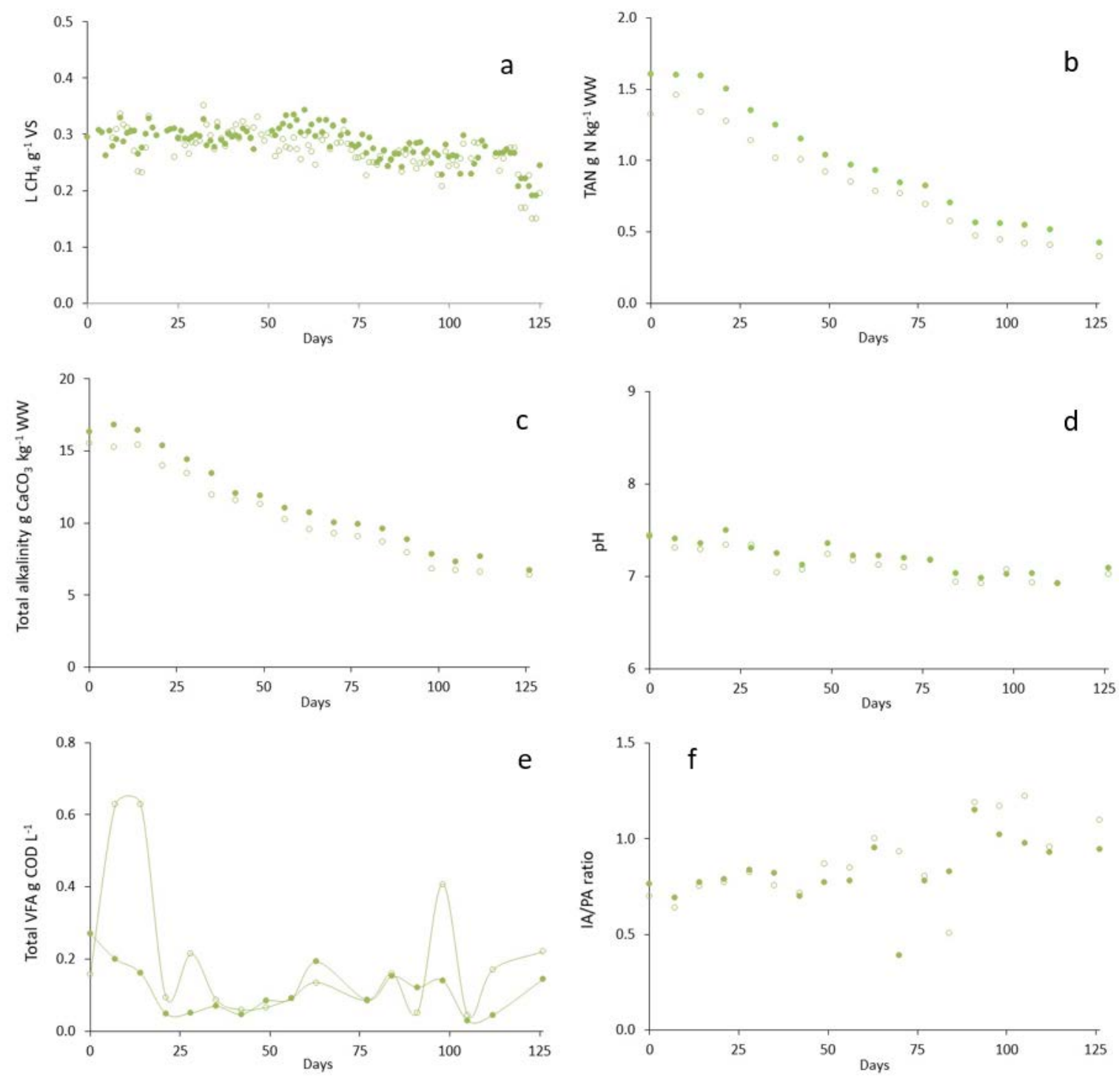

- D5 (Dilution) D6 (Dilution)

Fig. 4. Specific methane production, TAN, TA, $\mathrm{pH}$, total VFA and IA/PA ratio during anaerobic digestion of SBP at OLR $4 \mathrm{~g} \mathrm{VS} \mathrm{L}^{-1}$ day $^{-1}$ with feedstock dilution (SBP:water ratio $1: 1 \mathrm{w} / \mathrm{w})$. 

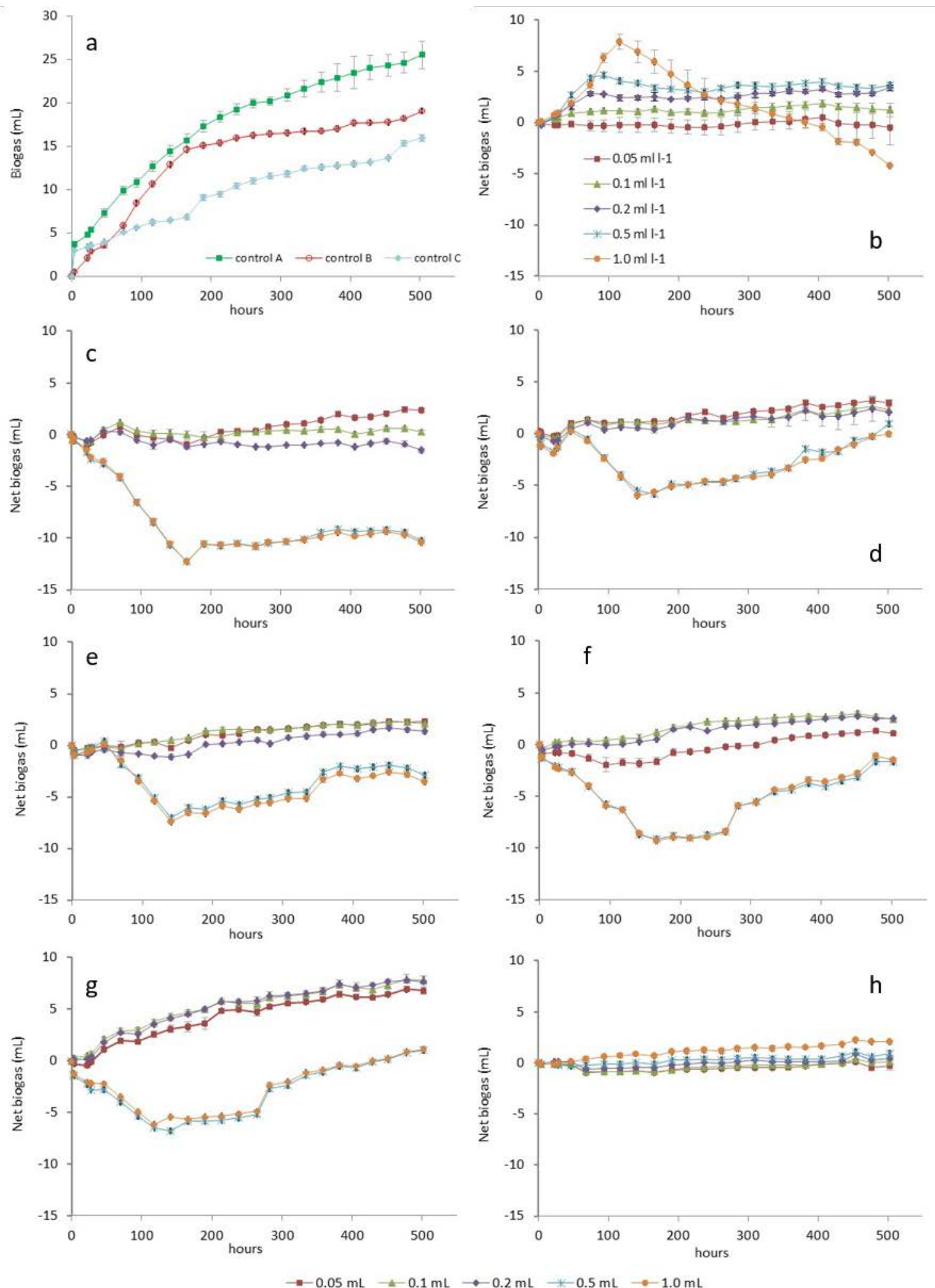

Fig. 5. Average control biogas and net biogas production in serum bottle toxicity tests with different types and doses of antifoams: (a) controls, (b) AF 530 with control A, (c) BC 86/103 with control B, (d) KemFoamX 2816 with control B, (e) KemFoamX 2125 with control B, (f) KemFoamX 2500 with control B, (g) KemFoamX 2641 with control B, and (h) J-QUELL-19 with control C. Average values are based on triplicate samples. If error bars are not seen, error is less than size of symbol. 

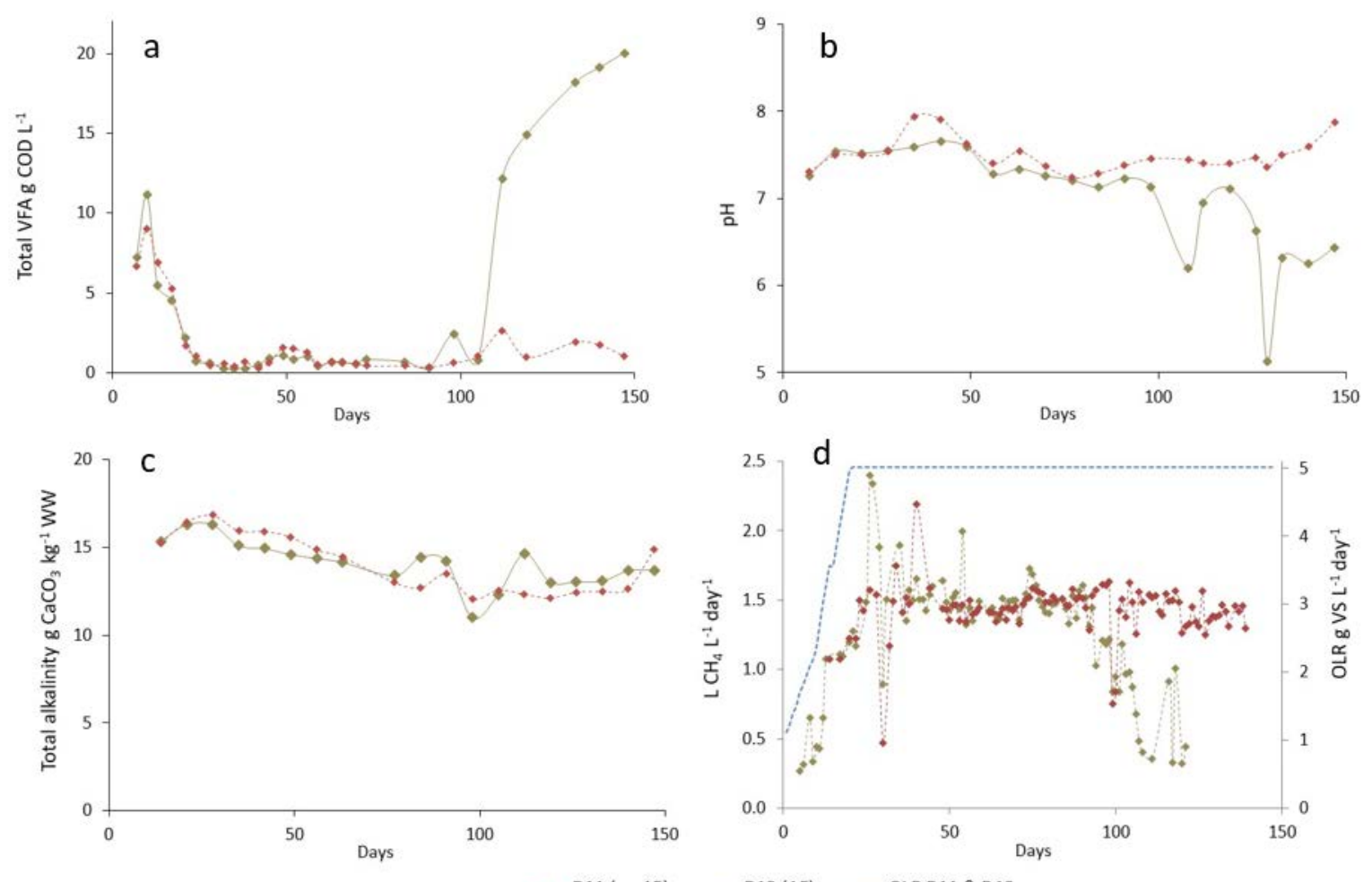

Fig. 6. Total VFA, pH, TA and volumetric methane production during anaerobic digestion of SBP at OLR 5 g VS L ${ }^{-1}$ day $^{-1}$ without (D11) and with (D12) antifoam addition.

\section{Tables}

Table 1. Experimental conditions for duplicate digesters in semi-continuous trials

\begin{tabular}{llccccc}
\hline Trial & Digester No. & $\begin{array}{c}\text { Capacity } \\
\text { (Working vol) } \\
\text { L }\end{array}$ & $\begin{array}{c}\text { Target } \\
\text { OLR } \\
\text { g VS L }^{-1} \\
\text { day }^{-1}\end{array}$ & $\begin{array}{c}\text { HRT at target } \\
\text { OLR } \\
\text { day }\end{array}$ & $\begin{array}{c}\text { Total } \\
\text { duration } \\
\text { day }\end{array}$ & Notes \\
\hline OLR & D1\&2 & $5(4)$ & 2 & 137.0 & 454 & $\begin{array}{l}\text { No added trace } \\
\text { elements (TE) }\end{array}$ \\
& D3\&4 & $5(4)$ & 3 & 91.3 & 383 & No TE \\
& D5\&6 & $5(4$ then 3) & 4 & 68.5 & 320 & No TE \\
& D7\&8 & $5(4$ then 3) & 5 & 54.8 & 327 & No TE \\
Antifoam & D9\&10 & $5(4)$ & 3 & 91.3 & 368 & TE \\
& D11 & $2(1)$ & 5 & 54.8 & 147 & TE \\
& D12 & $2(1)$ & 5 & 54.8 & 147 & TE and antifoam \\
\hline
\end{tabular}


Table 2. Performance indicators for semi-continuous digestion at different organic loading rates (average values during steady-state operating periods as shown)

\begin{tabular}{|c|c|c|c|c|c|c|c|c|c|}
\hline Parameter $^{\mathrm{a}}$ & Unit & $\mathrm{D} 1^{\mathrm{b}}$ & $\mathrm{D} 2^{\mathrm{b}}$ & $\mathrm{D}^{\mathrm{c}}$ & $\mathrm{D} 4^{\mathrm{c}}$ & D5 $^{d}$ & D6 $^{\mathrm{d}}$ & $\mathrm{D}^{\mathrm{e}}$ & D8 ${ }^{\mathrm{e}}$ \\
\hline OLR & $\begin{array}{l}\text { g VS L L } \\
\text { day }^{-1}\end{array}$ & 2 & 2 & 3 & 3 & 4 & 4 & 5 & 5 \\
\hline $\begin{array}{l}\text { Specific } \\
\text { biogas } \\
\text { production }\end{array}$ & $\mathrm{L} \mathrm{g}^{-1} \mathrm{VS}$ & $\begin{array}{c}0.633 \pm \\
0.063\end{array}$ & $0.626 \pm 0.055$ & $0.583 \pm 0.058$ & $0.586 \pm 0.080$ & $0.583 \pm 0.054$ & $0.593 \pm 0.045$ & $0.413 \pm 0.114$ & $0.586 \pm 0.047$ \\
\hline $\begin{array}{l}\text { Specific } \\
\text { methane } \\
\text { production }\end{array}$ & $\mathrm{L} \mathrm{g}^{-1} \mathrm{VS}$ & $\begin{array}{c}0.323 \pm \\
0.032\end{array}$ & $0.319 \pm 0.028$ & $0.298 \pm 0.029$ & $0.298 \pm 0.043$ & $0.301 \pm 0.025$ & $0.304 \pm 0.023$ & $0.204 \pm 0.060$ & $0.298 \pm 0.023$ \\
\hline $\begin{array}{l}\text { Vol. biogas } \\
\text { production }\end{array}$ & $\mathrm{L} \mathrm{L}^{-1}$ day $^{-1}$ & $1.27 \pm 0.13$ & $1.25 \pm 0.11$ & $1.75 \pm 0.17$ & $1.74 \pm 0.25$ & $2.32 \pm 0.21$ & $2.37 \pm 0.18$ & $1.94 \pm 0.68$ & $2.93 \pm 0.24$ \\
\hline $\begin{array}{l}\text { Vol. methane } \\
\text { production }\end{array}$ & $\mathrm{L} \mathrm{L} \mathrm{L}^{-1}$ day $^{-1}$ & $0.65 \pm 0.06$ & $0.64 \pm 0.06$ & $0.89 \pm 0.09$ & $0.89 \pm 0.13$ & $1.20 \pm 0.10$ & $1.22 \pm 0.09$ & $1.00 \pm 0.32$ & $1.49 \pm 0.12$ \\
\hline $\begin{array}{l}\text { Biogas } \\
\text { methane } \\
\text { content }\end{array}$ & $\%$ & $51.2 \pm 0.3$ & $50.8 \pm 0.3$ & $51.7 \pm 0.9$ & $51.6 \pm 1.0$ & $51.0 \pm 0.4$ & $50.7 \pm 0.4$ & $35.8 \pm 8.2$ & $50.8 \pm 0.4$ \\
\hline Digestate TS & $\mathrm{g} \mathrm{kg}^{-1} \mathrm{WW}$ & $55.9 \pm 1.5$ & $57.5 \pm 4.2$ & $63.6 \pm 1.6$ & $62.3 \pm 2.2$ & $66.1 \pm 3.8$ & $70.5 \pm 1.1$ & $73.5 \pm 4.1$ & $77.2 \pm 4.0$ \\
\hline Digestate VS & $\mathrm{g} \mathrm{kg}^{-1} \mathrm{WW}$ & $37.5 \pm 1.2$ & $40.5 \pm 4.3$ & $43.2 \pm 1.3$ & $42.5 \pm 0.6$ & $45.1 \pm 2.6$ & $49.5 \pm 1.2$ & $46.8 \pm 2.2$ & $54.8 \pm 3.7$ \\
\hline $\begin{array}{l}\text { VS } \\
\text { destruction }\end{array}$ & $\%$ & $91.0 \pm 0.3$ & $90.1 \pm 1.0$ & $91.0 \pm 0.2$ & $88.0 \pm 0.2$ & $87.3 \pm 0.7$ & $86.0 \pm 0.3$ & $85.4 \pm 1.7$ & $83.2 \pm 0.7$ \\
\hline $\mathrm{pH}$ & - & $7.56 \pm 0.08$ & $7.55 \pm 0.09$ & $7.37 \pm 0.10$ & $7.40 \pm 0.11$ & $7.45 \pm 0.11$ & $7.22 \pm 0.05$ & $6.48 \pm 0.32$ & $7.29 \pm 0.14$ \\
\hline TAN & $\begin{array}{l}\mathrm{g} \mathrm{N} \mathrm{kg}^{-1} \\
\mathrm{WW}\end{array}$ & $2.1 \pm 0.1$ & $2.1 \pm 0.0$ & $1.6 \pm 0.0$ & $1.6 \pm 0.0$ & $1.5 \pm 0.1$ & $1.3 \pm 0.0$ & - & $1.1 \pm 0.0$ \\
\hline $\begin{array}{l}\text { Total } \\
\text { alkalinity }\end{array}$ & $\begin{array}{l}\mathrm{g} \mathrm{CaCO}_{3} \\
\mathrm{~kg}^{-1} \mathrm{WW}\end{array}$ & $18.6 \pm 1.3$ & $18.8 \pm 0.2$ & $16.7 \pm 1.0$ & $16.0 \pm 0.2$ & $15.6 \pm 0.8$ & $15.5 \pm 0.6$ & $14.2 \pm 0.7$ & $13.1 \pm 1.1$ \\
\hline IA/PA ratio & - & $0.27 \pm 0.04$ & $0.28 \pm 0.03$ & $0.49 \pm 0.11$ & $0.40 \pm 0.02$ & $0.45 \pm 0.26$ & $0.40 \pm 0.15$ & $5.16 \pm 1.80$ & $0.46 \pm 0.16$ \\
\hline Total VFA & g COD L ${ }^{-1}$ & $0.07 \pm 0.04$ & $0.08 \pm 0.04$ & $0.12 \pm 0.06$ & $0.12 \pm 0.05$ & $0.16 \pm 0.03$ & $0.38 \pm 0.09$ & $18.33 \pm 7.55$ & $0.43 \pm 0.05$ \\
\hline
\end{tabular}

${ }^{a}$ Range shows \pm standard deviation on 4 or more measurements in the relevant period

b Average for day 411-439 (after 3 HRT in current conditions)

c Average for day 340-369 (after 3 HRT in current conditions)

d Average for day 292-320 (after 3 HRT in current conditions)

e Average for day 298-327 (last 30 days up to completion of 3 HRT) 
Table 3. Performance indicators for semi-continuous digestion trials with TE addition and dilution (average values during steady-state operating periods, with standard deviation)

\begin{tabular}{|c|c|c|c|c|c|}
\hline Parameter $^{\mathrm{a}}$ & Unit & D9 (with TE) ${ }^{b}$ & D10 (with TE) ${ }^{b}$ & $\mathrm{D}$ (dilution) $^{\mathrm{c}}$ & D6 (dilution) $^{c}$ \\
\hline OLR & $\begin{array}{l}\text { g VS L }{ }^{-1} \\
\text { day }^{-1}\end{array}$ & 3 & 3 & 4 & 4 \\
\hline $\begin{array}{l}\text { Specific biogas } \\
\text { production }\end{array}$ & $\mathrm{L} \mathrm{g}^{-1} \mathrm{VS}$ & $0.610 \pm 0.067$ & $0.612 \pm 0.062$ & $0.502 \pm 0.059$ & $0.471 \pm 0.085$ \\
\hline $\begin{array}{l}\text { Specific methane } \\
\text { production }\end{array}$ & $\mathrm{L} \mathrm{g}^{-1} \mathrm{VS}$ & $0.311 \pm 0.035$ & $0.314 \pm 0.032$ & $0.250 \pm 0.029$ & $0.189 \pm 0.083$ \\
\hline $\begin{array}{l}\text { Vol. biogas } \\
\text { production }\end{array}$ & $\mathrm{L} \mathrm{L}^{-1}$ day $^{-1}$ & $1.83 \pm 0.20$ & $1.84 \pm 0.18$ & $2.11 \pm 0.15$ & $1.95 \pm 0.16$ \\
\hline $\begin{array}{l}\text { Vol. methane } \\
\text { production }\end{array}$ & $\mathrm{L} \mathrm{L}^{-1} \mathrm{day}^{-1}$ & $0.93 \pm 0.10$ & $0.94 \pm 0.10$ & $1.05 \pm 0.07$ & $0.98 \pm 0.08$ \\
\hline $\begin{array}{l}\text { Biogas methane } \\
\text { content }\end{array}$ & $\%$ & $51.0 \pm 0.3$ & $51.3 \pm 0.3$ & 49.9 & 50.2 \\
\hline Digestate TS & $\mathrm{g} \mathrm{kg}^{-1} \mathrm{WW}$ & $63.4 \pm 1.5$ & $66.2 \pm 2.0$ & $37.3 \pm 1.8$ & $41.8 \pm 1.9$ \\
\hline Digestate VS & $\mathrm{g} \mathrm{kg}^{-1} \mathrm{WW}$ & $44.0 \pm 1.2$ & $44.4 \pm 0.7$ & - & $30.1 \pm 1.1$ \\
\hline VS destruction & $\%$ & $88.8 \pm 0.3$ & $88.8 \pm 0.2$ & $92.7 \pm 0.2$ & $91.8 \pm 0.2$ \\
\hline $\mathrm{pH}$ & - & $7.49 \pm 0.04$ & $7.50 \pm 0.04$ & $7.02 \pm 0.07$ & $6.99 \pm 0.07$ \\
\hline TAN & $\begin{array}{l}\mathrm{g} \mathrm{N} \mathrm{kg}^{-1} \\
\text { WW }\end{array}$ & $1.6 \pm 0.0$ & $1.8 \pm 0.0$ & $0.8 \pm 0.2$ & $0.7 \pm 0.2$ \\
\hline Total alkalinity & $\begin{array}{l}\mathrm{g} \mathrm{CaCO}_{3} \\
\mathrm{~kg}^{-1} \mathrm{WW}\end{array}$ & $17.2 \pm 0.3$ & $18.1 \pm 0.4$ & $7.4 \pm 0.5$ & $6.6 \pm 0.2$ \\
\hline IA/PA ratio & - & $0.28 \pm 0.01$ & $0.28 \pm 0.02$ & $0.97 \pm 0.04$ & $1.11 \pm 0.11$ \\
\hline Total VFA & $\mathrm{g} \mathrm{COD} \mathrm{L}^{-1}$ & 0.10 & 0.29 & $0.08 \pm 0.06$ & $0.17 \pm 0.17$ \\
\hline
\end{tabular}

a Range shows \pm standard deviation on 4 or more measurements in the relevant period

${ }^{\mathrm{b}}$ Average for day 327-356 (after 3 HRT in current conditions)

c Average for day 97-126 from start of dilution (last 30 days up to completion of 3 HRT)

Table 4. Foam reduction efficiency of different types of antifoam

\begin{tabular}{|c|c|c|c|c|c|}
\hline Antifoam & Type & Appearance & $\begin{array}{c}\text { Active } \\
\text { ingredient } \\
(\%)\end{array}$ & Company & $\begin{array}{c}\text { Foaming } \\
\text { reduction } \\
\text { efficiency } \\
(\%)\end{array}$ \\
\hline AF 530 & Silicone emulsion & $\begin{array}{l}\text { Milky off-white } \\
\text { liquid }\end{array}$ & - & $\begin{array}{l}\text { Goldencrest- } \\
\text { chemicals }\end{array}$ & 69.2 \\
\hline BC 86/103 & Silicone emulsion & $\begin{array}{l}\text { Translucent } \\
\text { yellowish grey } \\
\text { viscous liquid }\end{array}$ & 100 & $\begin{array}{l}\text { Basildon } \\
\text { chemical }\end{array}$ & 71.3 \\
\hline KemFoamX 2816 & Silicone emulsion & White, milky liquid & 23 & Kemira & 73.5 \\
\hline KemFoamX 2125 & $\begin{array}{l}\text { Water based fatty } \\
\text { alcohol emulsion }\end{array}$ & $\begin{array}{l}\text { White milky } \\
\text { emulsion }\end{array}$ & 24 & Kemira & 63.3 \\
\hline KemFoamX 2500 & $\begin{array}{l}\text { Oil free, ester } \\
\text { (surfactant) }\end{array}$ & Pale yellow liquid & 100 & Kemira & 73.5 \\
\hline KemFoamX 2641 & $\begin{array}{l}\text { Oil based } \\
\text { emulsifiable }\end{array}$ & Yellow opaque liquid & 100 & Kemira & 72.8 \\
\hline J-Quell 19 & $\begin{array}{l}\text { Mineral oil } \\
\text { defoamer }\end{array}$ & White, milky liquid & - & $\begin{array}{c}\text { J1 } \\
\text { Technologies }\end{array}$ & 74.8 \\
\hline
\end{tabular}




\title{
Antifoam, dilution and trace element addition as foaming control strategies in mesophilic anaerobic digestion of sugar beet pulp
}

\author{
S. Suhartini ${ }^{1,2}$, S. Heaven ${ }^{1}$, Yue Zhang ${ }^{1}$ and C. J. Banks ${ }^{1}$ \\ (E-mail: ssuhartini@ub.ac.id,sh7@soton.ac.uk, C.J.Banks@soton.ac.uk)
}

Corresponding author:

S. Suhartini, Department of Agroindustrial Technology, Faculty of Agricultural Technology, Universitas Brawijaya, Jl. Malang, 65145, Indonesia

E-mail: ssuhartini@ub.ac.id

\section{Supplementary Materials}

\section{BMP results}

A Biochemical Methane Potential (BMP) test was carried out over a 28-day period, ending when there was no net gas production from the samples with respect to the blank controls. Figure S1 shows the cumulative net specific biogas and methane production of the SBP and the cellulose positive controls, and also the cumulative production from the blank controls.
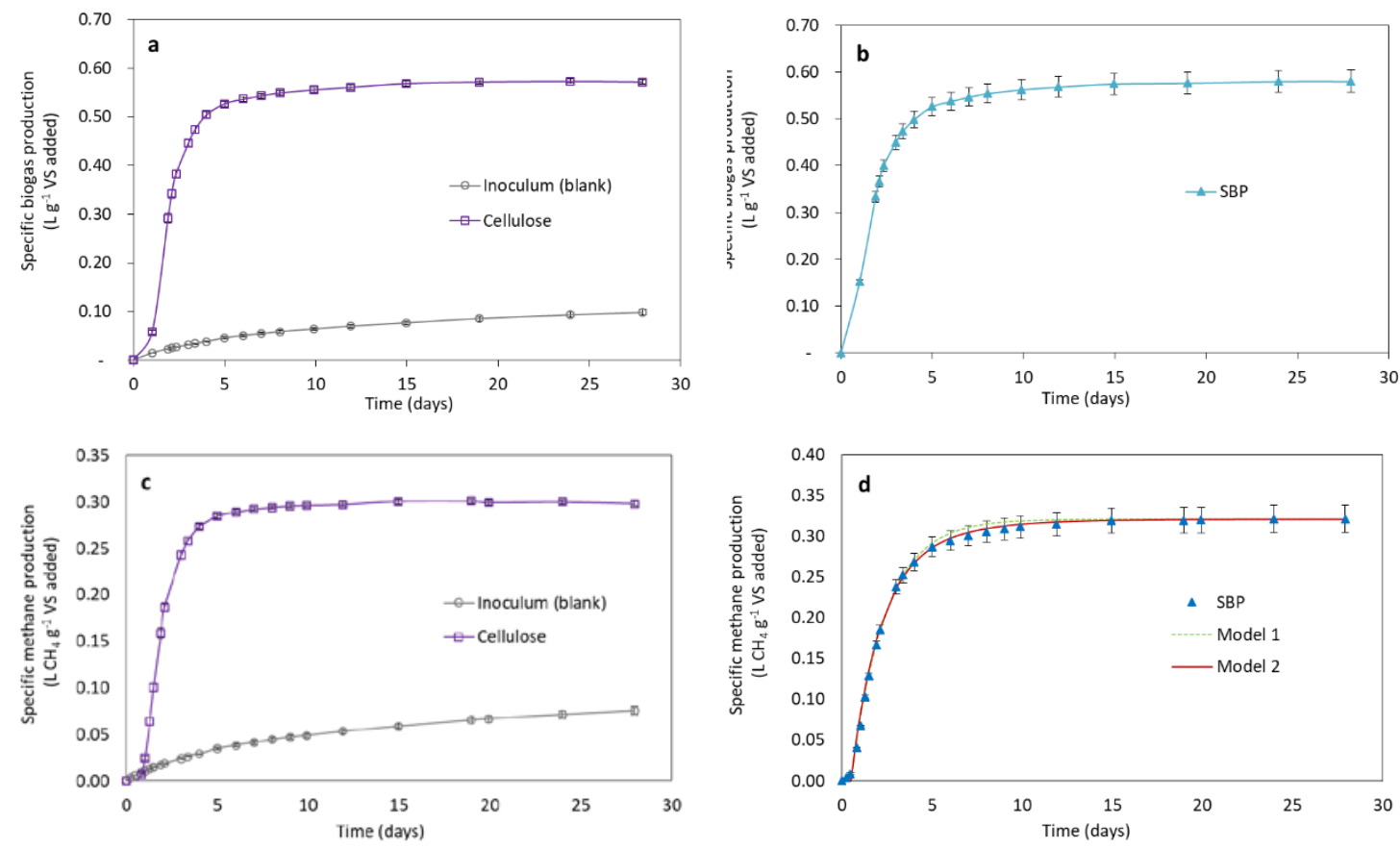

Figure S1. BMP test results: (a) cumulative net specific biogas production of positive controls and cumulative specific biogas production of blank controls; (b) cumulative net specific biogas production of SBP; (c) cumulative net specific methane production of positive controls and cumulative specific methane production of blank controls; (b) cumulative net specific methane production of SBP. Data are means of triplicate samples with error bars showing range. Where error bars are not visible, variation is smaller than symbol. 
The blank controls (inoculum only) reached a stable value after approximately 14 days with 28day specific biogas productions of $0.110,0.092$, and $0.092 \mathrm{~L} \mathrm{~g}^{-1} \mathrm{VS}$, giving an average value of $0.098 \mathrm{~L} \mathrm{~g}^{-1}$ VS. The cellulose positive controls showed rapid biogas production after a short lag time and reached a plateau after 10 days: the final specific biogas yields were 0.566, 0.568 and $0.581 \mathrm{~L} \mathrm{~g}^{-1} \mathrm{VS}$ with an average value of $0.572 \mathrm{~L} \mathrm{~g}^{-1} \mathrm{VS}$. SBP demonstrated the same trend as the positive control, showing a short lag time and reaching a plateau after 10 days with net specific biogas productions of $0.577,0.584$, and $0.653 \mathrm{~L} \mathrm{~g}^{-1} \mathrm{VS}$, giving an average value of $0.605 \mathrm{~L} \mathrm{~g}^{-1} \mathrm{VS}$.

The blank controls had specific methane productions of $0.084,0.071$, and $0.071 \mathrm{~L} \mathrm{CH}_{4} \mathrm{~g}^{-1} \mathrm{VS}$,; with an average value $0.075 \mathrm{~L} \mathrm{CH}_{4} \mathrm{~g}^{-1} \mathrm{VS}$. The cellulose positive controls had specific methane yields of $0.296,0.295$ and $0.303 \mathrm{~L} \mathrm{CH}_{4} \mathrm{~g}^{-1} \mathrm{VS}$ with an average of $0.298 \mathrm{~L} \mathrm{CH}_{4} \mathrm{~g}^{-1} \mathrm{VS}$. The controls all showed good agreement and the average specific methane yields were typical of values obtained for these materials (unpublished data, University of Southampton), indicating the assay conditions were acceptable. The final BMP values for the SBP were taken as $0.302,0.307$ and $0.355 \mathrm{~L} \mathrm{CH}_{4}$ $\mathrm{g}^{-1}$ VS with an average of $0.321 \mathrm{~L} \mathrm{CH}_{4} \mathrm{~g}^{-1} \mathrm{VS}$.

Table S1 shows the average values for $\mathrm{pH}$ and VFA concentration at the end of the BMP test. The $\mathrm{pH}$ was well within the acceptable value for the growth of anaerobic microorganisms No accumulation of VFA also indicated no inhibition of the degradation process.

Table S1. VFA concentration and $\mathrm{pH}$ value at end of BMP test (average values)

\begin{tabular}{lrrrrrrrrc}
\hline \multicolumn{1}{c}{ Sample } & \multicolumn{8}{c}{ VFA concentration $\left(\mathrm{mg} \mathrm{L}^{-1}\right)$} & $\mathrm{pH}$ \\
\cline { 2 - 8 } \multicolumn{1}{c}{ ID } & HAC & PRO & i-BUT & n-BUT & i-VAL & n-VAL & HEX & HEP & \\
\hline Blank & 23.0 & 2.2 & 2.6 & 4.3 & 8.3 & 7.5 & 13.2 & 17.5 & $7.36 \pm 0.0$. \\
Cellulose & 10.7 & 0.3 & n.d & 0.8 & 2.0 & 2.6 & 5.4 & 10.0 & $7.33 \pm 0.0$ \\
SBP & 12.2 & n.d & 0.8 & 1.2 & 4.0 & 2.5 & 4.7 & 7.5 & $7.34 \pm 0.0$ \\
\hline HAC = acetic acid, PRO = propionic acid, i-BUT = iso butyric acid, n-BUT = butyric acid, i-VAL = \\
iso valeric acid, n-VAL = valeric acid, HEX = hexanoic acid, HEP = heptanoic acid, n.d. = not detected \\
\hline
\end{tabular}

\section{BMP kinetics}

Two different kinetic models were fitted to the BMP data to simulate the performance of the digestion process: (i) A first-order model (equation S1)

$\mathrm{Y}=\mathrm{Y}_{\mathrm{m}}\left(1-\mathrm{e}^{-\mathrm{kt}}\right)$

[Equation S1]

Where:

$\mathrm{Y}$ is the cumulative methane yield at time $\mathrm{t}$ in $\mathrm{L} \mathrm{g}^{-1} \mathrm{VS}$ added

$\mathrm{Y}_{\mathrm{m}}$ is the ultimate methane yield in $\mathrm{L} \mathrm{g}^{-1} \mathrm{VS}$ added

$\mathrm{k}$ is the first order rate constant in day ${ }^{-1}$

$t$ is the time since the start of the test in days.

(ii) A pseudo-parallel first order model (equation S2) based on Rao et al. (2000).

$Y=Y_{m}\left(1-P e^{-k_{1} t}-(1-P) e^{-k_{2} t}\right)$

[Equation S2]

Where: 
$\mathrm{Y}$ is the cumulative methane yield at time $\mathrm{t}$ in $\mathrm{L} \mathrm{CH}_{4} \mathrm{~g}^{-1} \mathrm{VS}$ added

$\mathrm{Y}_{\mathrm{m}}$ is the ultimate methane yield in $\mathrm{L} \mathrm{CH}_{4} \mathrm{~g}^{-1}$ VS added

$\mathrm{k}_{1}$ is the first order rate constant for the proportion of readily degradable material in day ${ }^{-1}$

$\mathrm{k}_{2}$ is the first order rate constant for the proportion of less readily degradable material in day ${ }^{-1}$

$\mathrm{P}$ is the proportion of readily degradable material

$\mathrm{t}$ is the time since the start of the test in days.

The results for the two models, fitted with a lag time of 0.5 days, are shown in Figure S1d and the kinetic constants obtained are given in Table S2. Both models gave a good fit, with only a small improvement from the pseudo parallel equation S2. From Figure S1, it can be seen that about $90 \%$ of the methane had been produced after 7 days and $97 \%$ after 10 days indicating a rapid biodegradation rate.

Table S2. Kinetic constants from modelling with 0.5 day lag time

\begin{tabular}{|c|c|c|c|c|c|c|}
\hline$*($ & & $\mathrm{Y}_{\mathrm{m}}$ & $\mathrm{P}$ & $\mathrm{k}_{1}$ & $\mathrm{k}_{2}$ & $\begin{array}{c}\text { Correlation } \\
\text { coefficient } \mathrm{R}^{2}\end{array}$ \\
\hline \multirow[t]{2}{*}{ SBP } & Model 1 & 0.321 & 1 & 0.53 & - & 0.9981 \\
\hline & Model 2 & 0.321 & 0.77 & 0.65 & 0.27 & 0.9986 \\
\hline
\end{tabular}

\section{Calculation of residual gas production from SBP digestion}

At the end of the digestion trial the residual biogas and methane production was measured for digester D8 fed at OLR 5 g VS L ${ }^{-1}$ day $^{-1}$. A total of 37.3 L of biogas and 23.6 $\mathrm{L}$ of $\mathrm{CH}_{4}$ was produced in a period of 222 days after the cessation of feeding, giving specific residual biogas and

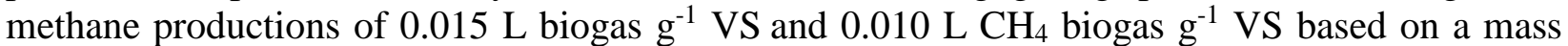
balance over the whole experimental period. Adding these values to the average specific methane production obtained in the semi-continuous trial at $5 \mathrm{~g} \mathrm{VS} \mathrm{L}^{-1}$ day $^{-1}$ gave a total of $0.319 \mathrm{~L} \mathrm{CH}_{4} \mathrm{~g}^{-}$ ${ }^{1} \mathrm{VS}$, close to the values found in the BMP test. Details of the calculation of residual gas production from semi-continuous digestion of SBP at OLR $5 \mathrm{~g} \mathrm{VS} \mathrm{L}^{-1}$ day $^{-1}$ are shown in Table S3.

Table S3. Calculation of specific residual and total biogas and methane production for semicontinuous digestion of SBP at OLR $5 \mathrm{~g} \mathrm{VS} \mathrm{L}^{-1}$ day $^{-1}$

\begin{tabular}{|c|c|c|c|}
\hline & Unit & Value & Note \\
\hline \multicolumn{4}{|l|}{ Semi-continuous trial } \\
\hline Total VS added & g VS & 14578 & A \\
\hline Total VS removed in digestate & g VS & 12004 & $\mathrm{~B}$ \\
\hline Total VS for conversion to biogas & g VS & 2574 & $C=A-B$ \\
\hline Specific biogas production & $\mathrm{L}$ biogas $\mathrm{g}^{-1} \mathrm{VS}$ & 0.586 & $\mathrm{D}$ \\
\hline Specific methane production & $\mathrm{L} \mathrm{CH}_{4} \mathrm{~g}^{-1} \mathrm{VS}$ & 0.298 & E \\
\hline \multicolumn{4}{|l|}{ Residual biogas production } \\
\hline Residual biogas produced & L biogas & 37.31 & $\mathrm{~F}$ \\
\hline Residual methane produced & $\mathrm{L} \mathrm{CH}_{4}$ & 23.55 & $\mathrm{G}$ \\
\hline Specific residual biogas production & $\mathrm{L}$ biogas $\mathrm{g}^{-1} \mathrm{VS}$ & 0.014 & $\mathrm{H}=\mathrm{F} / \mathrm{C}$ \\
\hline Specific residual methane production & $\mathrm{L} \mathrm{CH}_{4} \mathrm{~g}^{-1} \mathrm{VS}$ & 0.009 & $\mathrm{I}=\mathrm{G} / \mathrm{C}$ \\
\hline \multicolumn{4}{|l|}{ BMP test } \\
\hline Specific biogas production & L biogas $\mathrm{g}^{-1} \mathrm{VS}$ & 0.605 & $\mathrm{~J}$ \\
\hline
\end{tabular}


Specific methane production

$\mathrm{L} \mathrm{CH}_{4} \mathrm{~g}^{-1} \mathrm{VS}$

$0.321 \mathrm{~K}$

$C S T R+R B P$

Specific biogas production

L biogas $\mathrm{g}^{-1} \mathrm{VS}$

$0.600 \mathrm{~L}=\mathrm{D}+\mathrm{H}$

Specific methane production

$\mathrm{L} \mathrm{CH}_{4} \mathrm{~g}^{-1} \mathrm{VS}$

$0.307 \mathrm{M}=\mathrm{E}+\mathrm{I}$

These results confirmed that digestate from SBP has the potential to for additional methane production during post-digestion storage. Unless there is a requirement to store the digestate for other reasons, however, this capture may not be economically viable due to the required storage duration and volume, and improving the process performance followed by further treatment and utilisation of digestate may be a preferable option.

\section{$3 \quad$ Fluorescence in situ hybridisation}

Digesters D3 and D7 were sampled on day 213 and 223, respectively, for fluorescence in situ hybridisation (FISH) analysis using the technique described in Banks et al. (2012). Briefly, 10 $\mathrm{mL}$ of digestate was mixed with $90 \mathrm{~mL}$ of $1 \mathrm{x}$ phosphate buffer saline solution in a Waring blender for 1 min then density gradient centrifugation was conducted on the resulting homogenised diluted digestate for microbial biomass recovery. The oligonucleotide probes (Thermo Electron Biopolymers, Ulm, Germany) for FISH are given in Table S4.

Table S4. Oligonucleotide probes used with target groups

\begin{tabular}{llll}
\hline Probe name & Target group & Probe sequence (5’-3’) & Fluoro-chrome \\
\hline EUB338 & Bacteria (most) & GCTGCCTCCCGTAGGAGT & Cy5 \\
EUB338+ & Bacteria (remaining) & GCWGCCACCCGTAGGTGT & Cy5 \\
ARC915 & Archaea & GTGCTCCCCCGCCAATTCCT & 6-Fam \\
MSMX860 & Methanosarcinales & GGCTCGCTTCACGGCTTCCCT & Cy5 \\
MS1414 & Methanosarcinaceae & CTCACCCATACCTCACTCGGG & Cy3 \\
hMS1395 & MS1414-helper & GGTTTGACGGGCGGTGTG & - \\
hMS1480 & MS1414-helper & CGACTTAACCCCCCTTGC & - \\
\hline
\end{tabular}

Similar FISH images were obtained for both D3 and D7 digestate. The image of D7 is shown in Figure S2 and it can be seen that Methanosarcinaceae accounted for a high proportion of methanogen community. It is worth noting that the microbial biomass was present in flocs which could not be completely broken down by the above mentioned dilution and Waring blender homogenisation step. As a result, the depth of flocs on the microscope slide was greater than the depth of focus. For comparison purposes, Figure S3 provides a FISH image of biosolids digestate from Millbrook wastewater treatment works (Southampton, UK), which was used as the original inoculum for some of the work described, and which demonstrates clear biomass recovery without any apparent floc structure and boundary.

Although the probes used did not combine to any great extent with the extracellular polymeric substances (EPS) forming the floc, and the microorganisms present can still be distinguished, several pre-treatments were conducted after density gradient centrifugation to disrupt the flocs in order to get more focused FISH images. For sonication pre-treatment, $1 \mathrm{~mL}$ of recovered microbial biomass suspension was placed in a sonicator bath at $40^{\circ} \mathrm{C}$ for 20 minutes before performing FISH analysis. For mechanical pre-treatment, $1 \mathrm{~mL}$ of recovered suspension was mixed with 30 of $0.5 \mathrm{~mm}$ glass beads and put onto vortex mixer for 10 minutes. For enzymatic pre-treatment, $0.1 \mathrm{~mL}$ of a mixture of cellulase and xylanase was mixed with $1 \mathrm{~mL}$ of microbial 
biomass suspension at $50{ }^{\circ} \mathrm{C}$ for 1 hour and then put in a sonicator bath at $40{ }^{\circ} \mathrm{C}$ for 1 hour. The results indicated the microbial flocs were extremely resistant to these pre-treatments, and the floc size remained at least $30 \mu \mathrm{m}$ as before pre-treatment, as shown in Figure S4.

As only short rod and cocci-shaped microorganisms were identified in considerable percentages in both D3 and D7, it seems that the foaming problem was not induced by filamentous microorganisms. Currently there is no research work published on whether and how microbial flocs contribute to foaming, but the observed size of microbial flocs in SBP digesters indicates the flocs have potential to trap small gas bubbles and rise to the surface causing foaming.

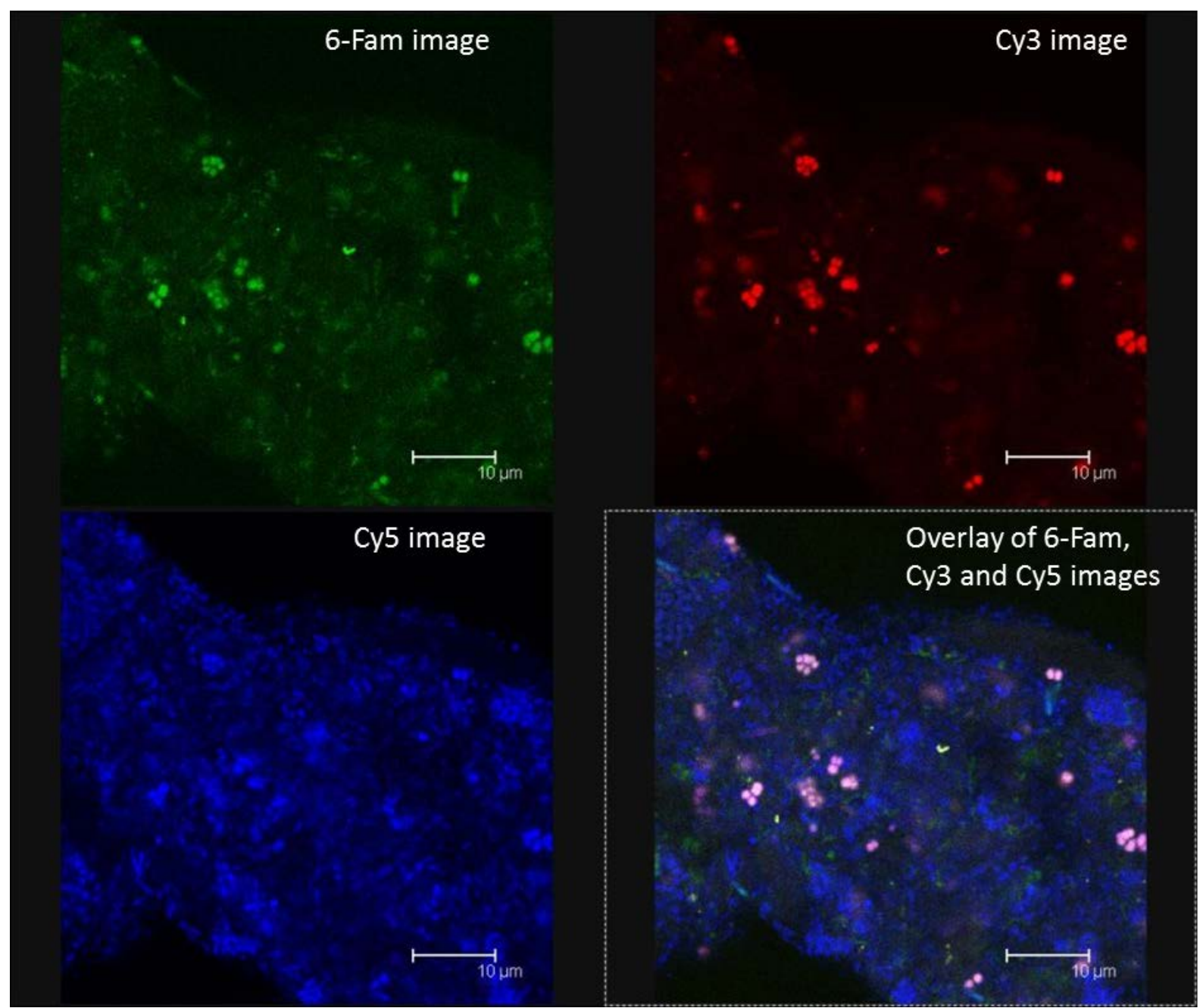

Figure S2. FISH image of D7. Note: Light blue overlay of ARC915 and MSMX860, and white (showing pink touch) overlay of ARC915, MSMX860 and MS1414. 


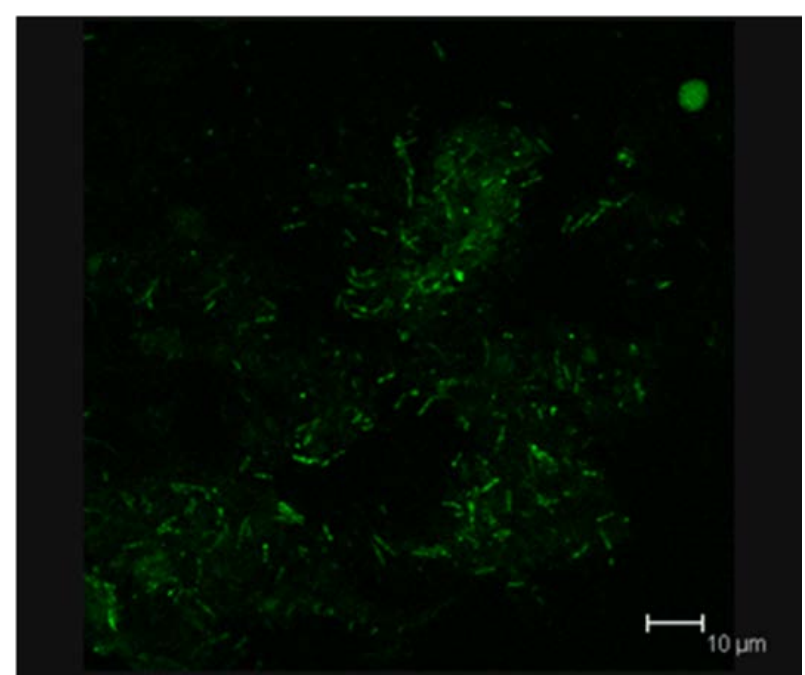

Figure S3. FISH image of biosolids digestate using Probe ARC915.

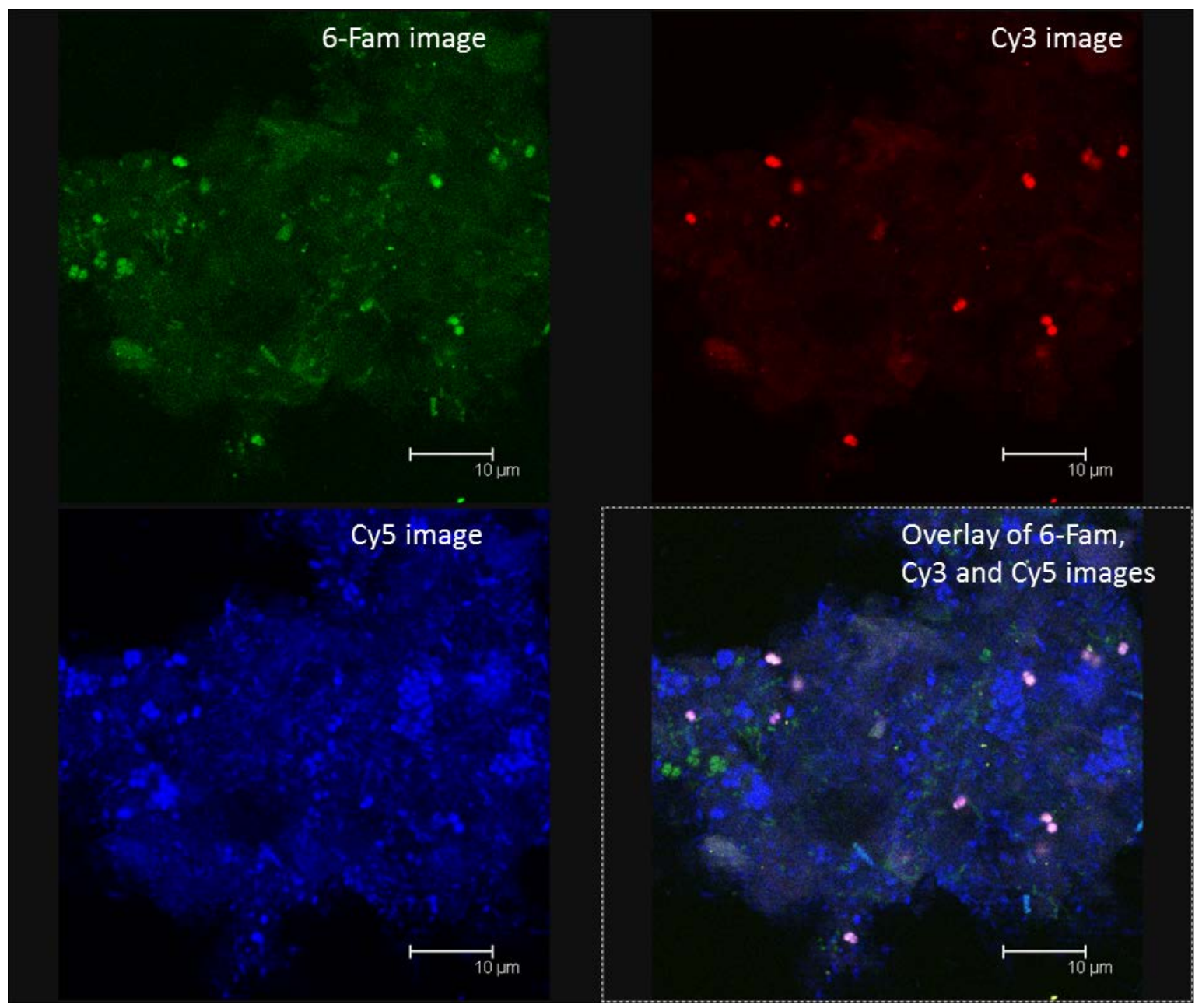

Figure S4. FISH image of D7 after combined ultrasonic and enzymatic pre-treatment. Note: Light blue overlay of ARC915 and MSMX860, and white (showing pink touch) overlay of ARC915, MSMX860 and MS1414. 


\section{$4 \quad$ Foam images}

Figure S5 shows images of foam from digester D11 without antifoam addition on day 180.
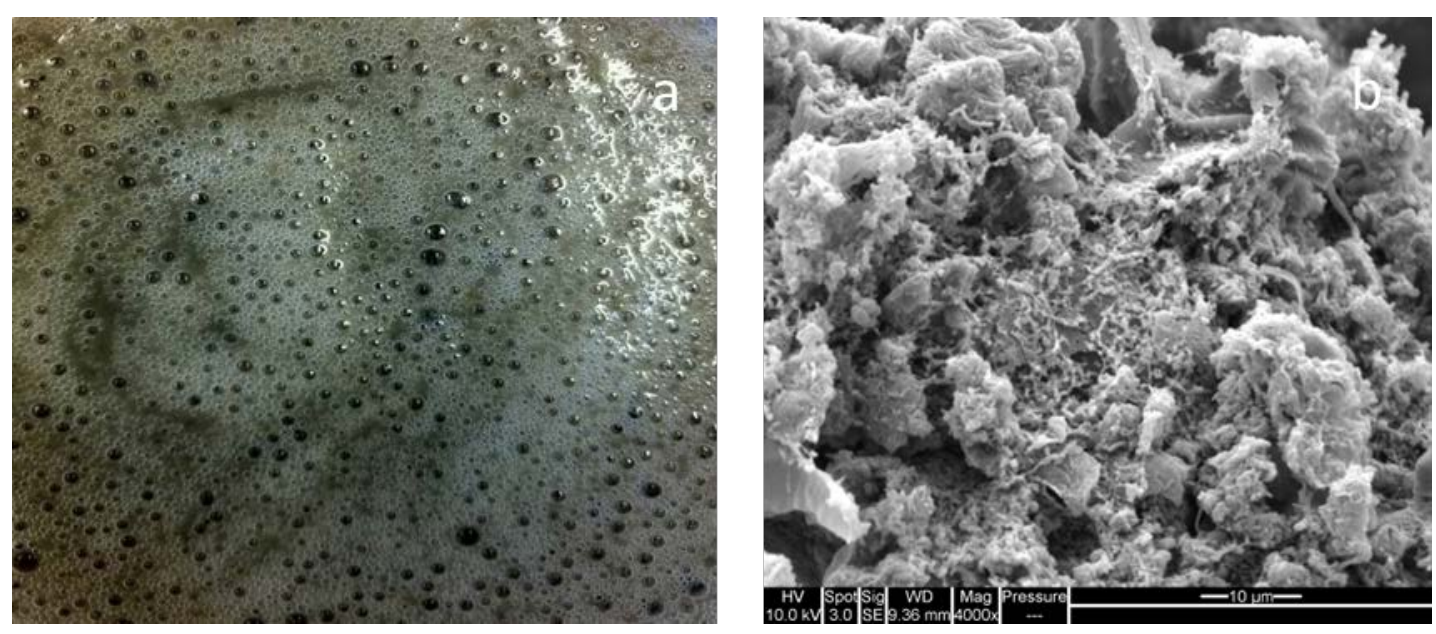

Figure S5. Foam images: (a) fresh foam in the digester and (b) SEM image (magnification of 4000x, $10 \mathrm{kV}$ and scale bar, $10 \mu \mathrm{m})$

\section{References}

Banks, C.J., Zhang, Y., Jiang, Y., Heaven, S., 2012. Trace element requirements for stable food waste digestion at elevated ammonia concentrations. Bioresour. Technol. 104, 127-135. https://doi.org/10.1016/j.biortech.2011.10.068.

Rao, M.S., Singh, S.P., Singh, A.K. and Sodha, M.S., 2000. Bioenergy conversion studies of the organic fraction of MSW: assessment of ultimate bioenergy production potential of municipal garbage. Applied energy, 66(1), pp.75-87. 